\title{
LOS DERECHOS ECONÓMICOS, SOCIALES Y CULTURALES COMO DERECHOS FUNDAMENTALES EFECTIVOS EN EL CONSTITUCIONALISMO DEMOCRÁTICO LATINOAMERICANO
}

\author{
The economic, social and cultural rights as an effective fundamental \\ rights in latin america democratic constitutionalism
}

\author{
Humberto Nogueira Alcalá ${ }^{1}$ \\ Profesor Titular de Derecho Constitucional \\ Universidad de Talca, Chile \\ nogueira@utalca.cl
}

Resumen: El artículo analiza desde la perspectiva del "bloque constitucional de derechos fundamentales" la naturaleza jurídica de los derechos sociales, su estructura jurídica, la inexistencia de diferencias esenciales con los derechos individuales, la indivisibilidad e interdependencia de los derechos individuales y sociales, su fuerza normativa directa y su aplicabilidad inmediata, irradiando todo el ordenamiento jurídico y los actos jurídicos de particulares, subordinando la autonomía de la voluntad y los contratos entre particulares, sus garantías y su justiciabilidad.

PALABRAS CLAVE: Derechos sociales; naturaleza jurídica de los derechos sociales; irradiación de todo el sistema jurídico y actos jurídicos de particulares; justiciabilidad.

ABSTRACT: The article analyzes from the perspective of the "fundamental block of constitutional rights" the legal nature of the social rights, your legal structure, the absence of essential differences with individual rights, the indivisibility and interdependence of individual and social rights, direct its legal force and direct and your immediate applicability, irradiating the entire legal system and specific legal acts, subordinating the autonomy and the legal contracts between privates, their security and justice.

1 Doctor en Derecho, Universidad Católica de Lovaina La Nueva, Bélgica. Director del Centro de Estudios Constitucionales de Chile, Universidad de Talca. Presidente de la Asociación Chilena de Derecho Constitucional. Vicepresidente del Instituto Iberoamericano de Derecho Procesal Constitucional. Miembro Asociado de la Academia Internacional de Derecho Comparado. Artículo recibido el 10 de septiembre de 2009, aprobado el 28 de octubre de 2009. 
KEYWORDS: Social rights; legal nature of the social rights; irradiation of the entire legal system and specific legal acts; justiciability.

\section{INTRODUCCIÓN}

El Estado Social y Democrático de Derecho o el Constitucionalismo Social estructura una imbricación diferente entre principios generales de la organización constitucional del Estado y garantías de los derechos fundamentales. Los derechos económicos, sociales y culturales inexistentes en el Estado Liberal vienen a complementar los derechos individuales y políticos, enriqueciendo la dignidad y el desarrollo de la persona humana y calificando la forma de Estado. En el Estado del constitucionalismo social los derechos económicos, sociales y culturales constituyen posiciones subjetivas de las personas que afirman un principio de igual dignidad e igualdad substantiva básica de todos los seres humanos. Los derechos económicos, sociales y culturales participan de las condiciones de verdaderos derechos en la medida que tengan un reconocido contenido esencial, además de ser disposiciones constitucionales de principio, todo lo cual tiene por objeto otorgar una mejor calidad de vida a las personas. Ello implica necesariamente la existencia de un Estado activo promotor del bien común y regulador del proceso económico social, proceso antes entregado a las fuerzas del libre mercado y a la sola iniciativa privada. En la nueva perspectiva del Estado Social, se asume la necesidad de brindar a la población un mínimo básico de bienestar que se compromete a entregar el Estado a través de prestaciones positivas de hacer respecto de las personas en salud, educación, condiciones laborales, seguridad social, sindicación, entre otras materias.

Las nuevas perspectivas del constitucionalismo social debe tener en consideración la crisis del Estado social tradicional del siglo XX, donde las políticas sociales tienen el carácter de concesiones planificadas centralmente por la administración, con fuertes niveles de opacidad, privilegios, discriminaciones y fenómenos de corrupción, como asimismo, con formas distorsionadas partitocráticas y la actuación de poderes invisibles e inmunes a los sistemas de adecuado control, todo lo cual, lleva a elevar los costos y a reducir la eficiencia y eficacia de las intervenciones destinadas a potenciar y maximizar los derechos sociales. ${ }^{2}$ Asimismo, deben considerarse las crisis económicas de las últimas décadas, las transformaciones productivas y tecnológicas, la globalización del sistema económico, las desregulaciones y privatizaciones introducidas en la perspectiva neoliberal de las últimas décadas, la creación de macropoderes económicos opacos, como asimismo, la deslocalización y destemporalización de las relaciones laborales.

La concepción de Estado Social de Derecho en la actualidad no es únicamente aquel en que la Constitución en forma expresa y solemne determina en una de sus disposicio-

2 Pisarello, Gerardo. (2002). "Del Estado social tradicional al Estado social constitucional: por una protección compleja de los derechos sociales”, en Carbonell, Miguel (Compilador) Teoría Constitucional y derechos fundamentales. (México, Ed. Comisión Nacional de Derechos Humanos), p. 116. 
nes la proclamación de un Estado Social y democrático de Derecho, como ocurre con Alemania, España o Colombia. Lo trascendente es que el ordenamiento jurídico asegure los derechos sociales y sus instituciones garantizadoras administrativas y jurisdiccionales, como normas jurídicas vinculantes y de efecto directo al menos en su contenido esencial, además del contenido mínimo de tales derechos asegurado por el derecho internacional; se desarrollen acciones jurisdiccionales idóneas para la protección de tales derechos; se establezcan límites a la autonomía de la voluntad y a la autonomía contractual en base al respeto de los derechos fundamentales; se institucionalice la función del Estado de promotor de tales derechos y de regulador del ámbito privado.

Ello obliga a fortalecer el Estado Constitucional democrático como nueva aproximación que fortalezca los derechos y sus garantías y consolide los principios de supremacía constitucional y de imperio de la juridicidad, la publicidad de las actuaciones del poder público y el control del poder.

\section{LA DIGNIDAD DE LA PERSONA COMO FUNDAMENTO DEL ESTADO DE DERECHO Y DEL CONSTITUCIONALISMO DEMOCRÁTICO SOCIAL CONTEMPORÁNEO}

Sólo al término de la Segunda Guerra Mundial todos los pueblos de la tierra inician una nueva etapa de convivencia pacífica, la que tiene como su fundamento la dignidad de la persona humana, tal como lo declararon los Estados reunidos en la Conferencia de San Francisco de 1945, aprobando la resolución de "reafirmar la fe en los derechos fundamentales del hombre, en la dignidad y el valor de la persona humana, en la igualdad de derechos de hombres y mujeres, y de las naciones grandes y pequeñas".

Luego la Asamblea General de Naciones Unidas del 10 de diciembre de 1948, que constituye el primer texto de alcance universal que reconoce la dignidad de la persona $\mathrm{y}$ los derechos esenciales o fundamentales que derivan de ella.

En efecto, el Preámbulo de la Declaración Universal de Derechos Humanos proclama su fe "en la dignidad y el valor de la persona humana" y determina que "todos los seres humanos nacen libres o iguales en dignidad y derechos $y$, dotados como están de razón y conciencia, deben comportarse fraternamente los unos con los otros".

La dignidad de la persona humana es el valor básico que fundamenta todos los derechos humanos, ya que su afirmación no sólo constituye una garantía, de tipo negativo que protege a las personas contra vejámenes y ofensas de todo tipo, sino que debe también afirmar positivamente a través de los derechos el pleno desarroIlo de cada ser humano y de todos los seres humanos. Cabe señalar que la dignidad humana y el derecho a una vida digna fundamenta tanto los derechos civiles y políticos como los derechos económicos, sociales y culturales. Todos los derechos tienen en tal perspectiva una dimensión positiva y negativa, ya que todos ellos requieren de prestaciones estatales que tienen costos económicos para su efectiva garan- 
tía, ${ }^{3}$ como son el funcionamiento de un aparato jurisdiccional eficaz del Estado, una policía competente, registros de propiedad, entre otros aspectos, como asimismo, una dimensión negativa o de abstención de vulneración tanto por el Estado (como una legislación que vulnere los derechos o que afecte su contenido esencial o la prohibición de retroceso sin justificación), como por los particulares, cuando estos realizan actos $u$ omisiones que afectan los derechos o adoptan actos jurídicos vulneradores de tales derechos.

Esta dignidad de la persona está dada por "la calidad intrínseca y distintiva reconocida en cada ser humano que lo hace merecedor del mismo respeto y consideración por parte del Estado y de la comunidad, implicando, en este sentido, un complejo de derechos y deberes fundamentales que aseguran a la persona tanto contra todo o cualquier acto de carácter degradante y deshumanizado, que vienen a garantizarle las condiciones existenciales mínimas para una vida saludable, además de propiciar y promover su participación activa y co-responsable en los destinos de la propia existencia y de la vida en comunión con los demás seres humanos, mediante el debido respeto a los demás seres que integran la red de la vida”. ${ }^{4}$

La dignidad de la persona es el valor jurídico supremo siendo independiente de la edad, capacidad intelectual o estado de conciencia. La dignidad de la persona es un elemento de la naturaleza del ser humano, corresponde a todos por igual, a diferencia de la honra o prestigio de las personas o de la dignidad de las funciones que la persona desarrolla, que son bienes que pueden aumentar, disminuir o incluso desaparecer, dependiendo de cada persona y de las circunstancias concretas.

La persona nunca pueden ser instrumento, sino que por su dignidad reclama un respeto de ser siempre sujeto y no objeto, por ser siempre fin en sí mismo, lo que llama al reconocimiento de su personalidad jurídica y todo lo que necesita para vivir dignamente.

La persona, en virtud de su dignidad, se convierte en fin del Estado: El Estado está al servicio de la persona humana y su finalidad es promover el bien común, para lo cual debe contribuir a crear las condiciones sociales que permitan a todos y a cada uno de los integrantes de la comunidad nacional su mayor realización espiritual y material posible, como asimismo, tiene el deber de promover la integración armónica de todos los sectores de la Nación y asegurar el derecho de las personas a participar con igualdad de oportunidades en la vida nacional.

De esta forma la dignidad de la persona constituye una realidad ontológica supraconstitucional al igual que los derechos que le son inherentes, el Estado y la Constitu-

3 Ver al respecto: Holmes, Stephan; Sumnstein, Cass. (1999). The cost of rights-Why liberty depends on taxes. W.W. (New York, Norton and Company). Galdino, Flavio. (2005). Introduçao a Teria dos Costos dos Direitos - Direitos nao nascen em árvores. (Río de Janeiro, Lumen Juris).

4 SArlet, Ingo Wolfgang. (2009). Dignidade da Pessoa Humana e Direitos Fundamentais na Constituicao Federal de 1988. Séptima edición revisada y actualizada. (Porto Alegre, Livraria do Advogado Editora), p. 67. 
ción sólo la reconocen y garantizan pero no la crean, así el Estado y el ordenamiento jurídico que lo regula debe excluir cualquier aproximación instrumentalizadora de la persona, toda visión sustancialista del Estado como fin en sí mismo.

La dignidad de la persona tiene un contenido integrador de los vacíos o lagunas existentes en el ordenamiento jurídico y en la propia Constitución, de reconocimiento de derechos implícitos.

La dignidad de la persona constituye el principio central de todo ordenamiento jurídico. Así lo ha afirmado también nuestro Tribunal Constitucional en sentencia de 26 de junio de 2008:

"Que de la dignidad que singulariza a toda persona humana se deriva un cúmulo de atributos, con los que nace y que conserva durante toda su vida. Entre tales atributos se hallan los derechos públicos subjetivos o facultades que el ordenamiento jurídico le asegura con carácter de inalienables, imprescriptibles e inviolables en todo momento, lugar y circunstancia. De esos atributos se nombran aquí, por su vínculo directo con la causa a ser decidida, el derecho a la vida, a la integridad física y psíquica y a la protección de la salud cuyo ejercicio legítimo la Constitución exige respetar siempre incluyendo la esencia inafectable de lo garantizado en ellos;". ${ }^{5}$

La misma sentencia nos precisa que:

"Que, en torno de la dignidad que singulariza a todo sujeto de la especie humana, se articula el sistema constitucional chileno, siendo menester poner de relieve que si la Carta Política asegura a todas las personas los derechos fundamentales, lo hace en el entendido que preexisten a ella; y que, en armonía con lo preceptuado en el artículo $5^{\circ}$, inciso segundo, los órganos públicos y privados, en ejercicio de la competencia y facultades, respectivamente, que les han conferido la Constitución y la ley, no sólo están obligados a respetar esos derechos, sino que, además, a protegerlos y promoverlos;" ${ }^{\circ}$

Siguiendo a Maihofer, la garantía de la dignidad de la persona tiene un triple significado jurídico, en primer lugar, se constituye en un derecho esencial, a partir del cual se pueden deducir todos los demás componentes del sistema de derechos esenciales o derechos humanos, en segundo lugar, constituye una norma fundamental de la Carta Fundamental, por relación a la cual cabe dirimir la validez de otras normas que la componen, en tercer lugar, constituye la base material sobre la cual se construye la estructura organizativa del Estado.

Debemos precisar que la persona humana no es una abstracción ni un individuo aislado, la persona es un ser social, convive con las demás personas en sociedad y actúa

5 Sentencia del Tribunal Constitucional, de 26 de junio de 2008 , Rol $\mathrm{N}^{\circ}$ 976, considerando vigesimotercero.

6 Sentencia del Tribunal Constitucional, de 26 de junio de 2008 , Rol $N^{\circ} 976$, considerando vigesimocuarto. 
en el complejo mundo de la vida social y política. Asimismo, los derechos que se fundamentan en la dignidad de la persona humana deben ser examinados no en forma aislada sino formando parte del complejo sistema de derechos, los que se interrelacionan y se limitan recíprocamente, como asimismo deben armonizarse con los derechos de las demás personas dentro de un marco social y político dirigido al bien común.

Todo el derecho internacional de los derechos humanos como el derecho constitucional latinoamericano se basa en la dignidad intrínseca de la persona humana y la protección de los derechos que de ella derivan.

Esta concepción de la dignidad humana exige que tanto los ordenamientos jurídicos nacionales como internacionales en materia de derechos fundamentales aseguren, respeten, promuevan y garanticen un cierto nivel de bienestar material y social, que constituye a los derechos sociales fundamentales en derechos indivisibles y complementarios de los derechos civiles y políticos.

A su vez, a nivel planetario ya se aprobó en Nueva York el 19 de diciembre de 1966, el Pacto Internacional de Derechos Económicos, Sociales y Culturales con un fundamento similar al Pacto Internacional de Derechos Civiles y Políticos, donde los Estados Partes se comprometen a reconocer y garantizar los derechos que el pacto asegura, el cual entra en vigencia el 3 de enero de 1976.

En el ámbito americano la Declaración Americana de Derechos y Deberes del Hombre que es de fecha 2 de mayo de 1948, dada en la IX Conferencia Interamericana desarrollada en Bogotá, Colombia, y por tanto, anterior en varios meses a la Declaración Universal, se complementará con la Convención Americana de Derechos Humanos, aprobada en San José, Costa Rica, el 22 de noviembre de 1969, cuyo artículo 11.1 establece el principio esencial de que "Toda persona tiene derecho al (...). reconocimiento de su dignidad" y con el Protocolo de San Salvador, correspondiente a la Convención de Derechos Económicos, Sociales y Culturales en el ámbito americano.

Todo ello muestra el proceso de ir concretando a través de aproximaciones sucesivas una mayor humanización de la sociedad y una mayor personalización de los individuos, en una democracia participativa y una convivencia más justa y pacífica en el marco del Estado Constitucional democrático.

El derecho cumple así una función promocional como señala Norberto Bobbio, debiendo promover condiciones más humanas de vida y removiendo obstáculos para hacer efectivas la dignidad de la persona, la libertad y la igualdad, con miras a la plenitud del ejercicio de los derechos. Tal perspectiva promocional de los derechos fundamentales está expresamente contenida en la Constitución chilena en el artículo 5, inciso $2^{\circ}$, el cual determina: "Es deber de los órganos del Estado respetar y promover tales derechos, garantizados por esta Constitución, así como por los tratados internacionales ratificados por Chile y que se encuentran vigentes". 
La labor interpretativa constitucional requiere de una reconstrucción de todo el contenido que establece el complejo normativo de la Constitución, la lectura e interpretación de todo precepto de la Carta Fundamental debe ser hecho en su contexto, teniendo en consideración los principios, valores, fines y razón histórica del ordenamiento constitucional, constituyendo un deber del Estado y de sus órganos, como establece el inciso final del artículo $1^{\circ}$ de la Constitución "promover la integración armónica de todos los sectores de la Nación y asegurar el derecho de las personas a participar con igualdad de oportunidades en la vida nacional”. Esta perspectiva otorga al Juez Constitucional un espacio significativo de movilidad interpretativa e integradora que lo convierte en un protagonista activo y significativo en la mediación entre la Constitución y la situación específica, promoviendo la integración y una igualación efectiva de oportunidades en el ámbito político, social, cultural y económico, lo que tiende a fortalecer la legitimidad del sistema democrático constitucional.

\section{EL BLOQUE CONSTITUCIONAL DE DERECHOS FUNDAMENTALES EN EL CONSTITUCIONALISMO LATINOAMERICANO}

Asimismo, como ya hemos explicitado en diversos artículos y libros, ${ }^{7}$ nuestro constitucionalismo latinoamericano, se ha distinguido en el concierto internacional en las últimas tres décadas por asegurar los derechos fundamentales en base no sólo a la explicitación formal de los derechos asegurados constitucionalmente sino también incorporando a estos los derechos asegurados por las fuentes formales del derecho internacional.

Para ello el intérprete y operador jurídico debe utilizar el bloque constitucional de derechos fundamentales, por el cual entendemos el conjunto de derechos de la persona ( atributos) asegurados por fuente constitucional o por fuentes del derecho internacional de los derechos humanos (tanto el derecho convencional como el derecho consuetudinario y los principios de ius cogens) y los derechos implícitos, expresamente incorporados a nuestro ordenamiento jurídico por vía del artículo 29 literal c) de la $\mathrm{CADH},{ }^{8}$ todos los cuales, en el ordenamiento constitucional chileno, constituyen límites a la soberanía, como lo especifica categóricamente el artículo $5^{\circ}$ inciso segundo de la Constitución chilena vigente.?

El bloque de derechos fundamentales queda configurado, como lo hemos ya determinado en el primer capítulo del primer tomo de este texto, por:

Por todos, Nogueira Alcalá, Humberto. (2008). Derechos fundamentales y garantías constitucionales. (Santiago, Ed. Librotecnia), Capítulo I.

8 Dicha disposición establece lo siguiente: “Artículo 29. Normas de interpretación. Ninguna disposición de la presente Convención puede ser interpretada en el sentido de: C) Excluir otros derechos o garantías que son inherentes al ser humano o que se derivan de la forma democrática representativa de gobierno".

9 Sobre esta materia consultar NogueIra AlcalÁ, Humberto. (2003). Los derechos esenciales o humanos contenidos en los tratados internacionales y su ubicación en el ordenamiento jurídico nacional: doctrina y jurisprudencia. En Revista lus et Praxis, año $9 \mathrm{~N}^{\circ}$ 1, 2003. pp. 403-466. 
a) Los que la Carta Fundamental explicita sin taxatividad;

b) Los derechos implícitos.

c) Los que asegura el derecho internacional a través de los principios de ius cogens; ${ }^{10}$ el derecho convencional internacional de derechos humanos y derecho internacional humanitario ${ }^{11}$ y el derecho internacional consuetudinario.

En tal sentido, tal como ocurre con los derechos individuales y políticos, también pasan a integrarse como atributos de los derechos sociales asegurados constitucionalmente los atributos asegurados por el Pacto Internacional de Derechos Económicos, Sociales y Culturales de Naciones Unidas, debidamente ratificado por el Estado chileno y plenamente vigente. A ello deben agregarse otras disposiciones de derecho convencional internacional o derecho consuetudinario internacional, entre ellos los Convenios de la Organización Internacional del Trabajo.

Todas las normas sobre derechos fundamentales sociales contenidas en nuestro ordenamiento jurídico deben ser interpretadas armónicamente con las respectivas fuentes normativas de derecho interno como las fuentes convencionales internacionales (que son, a la vez, derecho interno, ya que se han incorporado tales derechos por mandato del constituyente originario a nuestro orden jurídico, constituyendo límites a la soberanía), con las claves hermenéuticas del Derecho de los Derechos Humanos y sus órganos de aplicación, en especial, en el ámbito regional americano, por la Corte Interamericana de Derechos Humanos; en el ámbito mundial por el Comité de Derechos Económicos, Sociales y Culturales de Naciones Unidas; el Comité de Expertos y el Comité de Libertad Sindical de la OIT.

El Derecho Internacional de los Derechos Humanos en materia de derechos sociales es fuente del Derecho Interno cuando contiene elementos que enriquecen al Derecho Interno, cuando agregan un "plus" al contenido normativo de los derechos delimitados y configurados en el derecho interno y viceversa, buscando siempre la integralidad maximizadora del sistema de derechos esenciales o humanos. Asimismo, deben utilizarse los postulados básicos de interpretación de derechos humanos "favor persona”, utilizado ya por nuestro Tribunal Constitucional. ${ }^{12}$

El intérprete constitucional debe entender que existe una retroalimentación recíproca entre fuente interna y fuente internacional recepcionada internamente en mate-

10 Ellos han sido incorporados al derecho interno mediante la Convención de Viena sobre Derecho de los Tratados, ratificada por Chile y vigente desde 1981, cuyo artículo 53 determina: "una norma imperativa de derecho internacional general es una norma aceptada y reconocida por la comunidad internacional de Estados en su conjunto como norma que no admite acuerdo en contrario y que sólo puede ser modificada por una norma ulterior de derecho internacional general que tenga el mismo carácter".

11 La Convención de Viena establece en el artículo 26: "Todo tratado en vigor obliga a las partes y debe ser cumplido por ellas de buena fe", y en el artículo 27: "Una parte no podrá invocar las disposiciones de su derecho interno como justificación del incumplimiento de un tratado".

12 Sentencia del Tribunal Constitucional chileno, Rol $N^{\circ}$ 740-07, de 18 de abril de 2008, considerando 69. Sentencia del Tribunal Constitucional, Rol 1361-09, de trece de mayo de dos mil nueve, considerando $73^{\circ}$. 
ria de derechos fundamentales. En la misma perspectiva debe existir una retroalimentación entre el intérprete final del derecho interno y el intérprete final del derecho regional o internacional de derechos humanos, especialmente, de aquel que el Estado ha comprometido a respetar y garantizar ante la comunidad internacional.

Los derechos sociales fundamentales explícitos están contenidos en el texto constitucional, sus atributos esenciales se complementan con aquellos asegurados por los atributos y garantías de tales derechos contenidos en el derecho internacional de los derechos humanos válidamente incorporado y vigente, en la medida que según el propio derecho internacional son derivaciones de la dignidad o atributos de la persona humana, como sostienen los mismos tratados o convenciones internacionales. A su vez, puede sostenerse la existencia de derechos sociales fundamentales implícitos obtenidos por vía de interpretación sistemática con una correcta justificación constitucional.

\section{LOS DERECHOS ECONÓMICOS, SOCIALES Y CULTURALES COMO DERECHO INDIVISIBLES E INTERDEPENDIENTES CON LOS DERECHOS INDIVIDUALES Y POLÍTICOS}

Los derechos económicos, sociales y culturales conforman junto con los derechos individuales y políticos los soportes básicos del sistema de derechos fundamentales, como asimismo, todos ellos constituyen derivaciones de la dignidad intrínseca de la persona humana y se fundamentan en ellos.

En la Conferencia de Derechos Humanos de Teherán de 1968, ya se proclamó la indivisibilidad e interdependencia de los derechos humanos, precisando "que la plena realización de los derechos civiles y políticos es imposible sin el goce de los derechos económicos, sociales y culturales". ${ }^{13}$

La Asamblea General de Naciones Unidas, en la Resolución 32/130 de 16 de diciembre de 1977, según recuerda Casal, determinó que:

“a) Todos los derechos humanos y libertades fundamentales son indivisibles e interdependientes, deberá prestarse la misma atención y urgente consideración a la aplicación, la promoción y protección tanto de los derechos civiles y políticos como de los derechos económicos, sociales y culturales;

“b) 'La plena realización de los derechos civiles y políticos sin el goce de los derechos económicos, sociales y culturales resulta imposible; la consecución de un progreso duradero en la aplicación de los derechos humanos depende de

13 Ver Cançado Trindade, António. Protección Internacional de los derechos económicos, sociales y culturales. En Estudios Básicos de Derechos Humanos; I, San José, Costa Rica, Instituto Interamericano de Derechos Humanos, pp. 39 y ss. 
unas buenas y eficaces políticas nacionales e internacionales de desarrollo económico y social', como lo reconoce en la proclamación de Teherán de 1968". ${ }^{14}$

A su vez, como señala Afonso Da Silva, en la Conferencia Mundial de Derechos Humanos de Viena de junio de 1993, en la Declaración y el Programa de Acción de Viena, se determina en su artículo $5^{\circ}$ : "Todos los derechos humanos son universales, indivisibles e interdependientes y están relacionados entre sí. La comunidad internacional debe tratar los derechos de forma global y de manera justa y equitativa, en pie de igualdad y dándoles a todos un mismo peso. Debe tenerse en cuenta la importancia de las particularidades nacionales y regionales, así como los diversos patrimonios históricos, además los Estados tienen el deber, sean cuales fueren sus sistemas políticos, económicos y culturales, de promover y proteger todos los derechos humanos y las libertades fundamentales". ${ }^{15}$

Los derechos económicos, sociales y culturales en cuanto derechos sociales fundamentales explicitan las exigencias de los valores de dignidad, igualdad y de solidaridad humana, buscando superar las desigualdades sociales, generando el derecho de participar en los beneficios de la vida social, o al menos a un mínimo vital compatible con la dignidad humana a través de derechos y prestaciones brindadas directa o indirectamente por los poderes públicos. ${ }^{16}$

Como establece la Declaración de Quito del 24 de julio de 1998 en su preámbulo [...] los derechos económicos, sociales y culturales (DESC), al igual que los civiles y políticos, son parte indisoluble de los derechos humanos y del derecho internacional de los derechos humanos, tal como constan en la Declaración Universal, el Pacto Internacional de los Derechos Económicos, Sociales y Culturales, la Declaración Americana de los Deberes y Derechos del Hombre, la Declaración sobre garantías sociales, la Convención Americana sobre Derechos Humanos y el protocolo Facultativo de San Salvador".

Dicha Declaración de Quito, en sus principios generales nos recuerda que:

"13. La fuente de todos los derechos humanos es la dignidad humana. La democracia, la justicia, la paz, el desarrollo y el respeto de los derechos humanos y las libertades fundamentales son conceptos interdependientes que se refuerzan mutuamente.

14 Casal, Jesús Maria. (2007). "La protección internacional y constitucional de los derechos sociales". Casal, Jesús María; ArIsmendi, Alfredo y Carrillo, Carlos Luis (coordinadores). Tendencias actuales del derecho constitucional. Homenaje a Jesús María Casal Montbrun. Tomo II. (Caracas, Ed. Universidad Central de Venezuela - Universidad Católica Andrés Bello), p. 11.

15 Afonso da SiLva, José. (2002). Impacto da Declaração Universal dos Direitos Humanos na Constituição Brasileira. En Palomino Manchego, José y Remotti Carbonell, José Carlos (Coordinadores). Derechos Humanos y Constitución en Iberoamérica. Lima, Ed. Universidad Nacional de San Marcos - Instituto Iberoamericano de Derecho Constitucional [sección peruana]), pp. 158-159.

16 Ver Aranco, Rodolfo. (2005). El concepto de derechos sociales fundamentales. (Bogotá, Ed. Legis, Universidad Nacional de Colombia), pp. 37 y ss. 
“14. Los derechos humanos son universales, indivisibles, interdependientes y exigibles, y los dos tienen el mismo estatuto legal, importancia y urgencia que los derechos civiles y políticos.

“15. El goce de los derechos económicos, sociales y culturales es determinante para la posibilidad de un goce efectivo, igualitario y no discriminatorio de los derechos civiles y políticos. Asegurar el goce de los derechos civiles y políticos sin considerar el pleno ejercicio de los derechos económicos, sociales y culturales conlleva discriminaciones intolerables que favorecen a los sectores beneficiados por la desigual distribución de la riqueza y reproducen las inequidades sociales.”

De acuerdo a dichos instrumentos internacionales los derechos económicos, sociales y culturales son derechos indivisibles e interdependientes de los derechos civiles y políticos, debiendo todos ellos ser respetados, promovidos y garantizados. Como ha establecido el Comité de Derechos Económicos, Sociales y Culturales de Naciones Unidas en su Observación General $N^{\circ} 3$, referida a la índole de las obligaciones de los Estados Partes (de los poderes públicos y autoridades dentro de ellos), son las de respetar, proteger y cumplir o realizar los derechos, pormenorizando dicha Observación General cada una de estas obligaciones.

Ello obliga a los estados parte de dichos Pactos o Convenciones de abstenerse de realizar acciones u omisiones que constituyan una vulneración de los derechos asegurados como asimismo, requiere que el Estado realice medidas, acciones y adopción de normas jurídicas para impedir que otros actores privados violen los derechos de otras persona, además de realizar las acciones preventivas necesarias para ello. Asimismo, el Estado parte tiene la obligación de adoptar medidas positivas para asegurar el ejercicio de tales derechos a todas las personas utilizando para ello el máximo de sus recursos disponibles, incluyendo la ayuda internacional al respecto, sin perjuicio, de garantizar el mínimo de cada derecho asegurado por el derecho internacional vinculante.

Estas obligaciones tienen su fuente básica en el artículo 2 del PIDESC, el cual determina que:

"Cada uno de los Estados Partes en el Presente Pacto se compromete a adoptar medidas, tanto por separado como mediante la asistencia y la cooperación internacionales, especialmente económicas y técnicas, hasta el máximo de los recursos de que disponga, para lograr progresivamente, por todos los medios apropiados, inclusive en particular la adopción de medidas legislativas, la plena efectividad de los derechos aquí reconocidos."

El Comité de Derechos Económicos, Sociales y Culturales de Naciones Unidas, afirma, a partir del texto del artículo 2 explicitado, la existencia para los Estados Partes de obligaciones de conducta y obligaciones de resultado.

La obligación de conducta, tanto activa como pasiva, señala un determinado comportamiento que debe ser realizado por el Estado parte y todos sus órganos y autoridades de realizar determinadas acciones o de abstenerse de ellas. Como por ejemplo 
el hecho de que los agentes y autoridades del Estado no pueden desarrollar acciones discriminatorias respecto del ejercicio del derecho al trabajo por hombres y mujeres o deben abstenerse de afectar la prohibición de trabajo infantil.

La obligación de resultado tiene relación con el cumplimiento de determinados objetivos, como la eliminación de situaciones de hambre de la población, de prevención de epidemias el de establecimiento de remuneraciones justas, el de respetar el derecho de sindicación y de libertad de asociación sindical, modificar el ordenamiento jurídico interno para efectivizar las obligaciones convencionales, diagnosticar el estado de cumplimiento de las obligaciones en materia de derechos sociales y desarrollar una estrategia destinada a concretarlos, asegurar acciones judiciales y recursos administrativos destinadas a garantizar los derechos sociales, los cuales sean accesibles, idóneos, rápidos, eficaces; dotar de sustantividad procesal a los derechos colectivos y los derechos difusos.

\section{LA AUSENCIA DE DIFERENCIAS ESTRUCTURALES BÁSICAS DE LOS DERECHOS INDIVIDUALES Y DE LOS DERECHOS SOCIALES}

Los derechos económicos, sociales y culturales son derechos humanos o fundamentales que implican no solo prestaciones positivas estatales, sino también la ausencia de interferencia arbitraria de terceros, aseguradas por normas constitucionales o del derecho internacional de los derechos humanos, al igual que los derechos civiles y políticos, todos los cuales posibilitan una mejor realización de la dignidad humana. Los derechos sociales constituyen presupuestos y complementos indivisibles del goce de los derechos individuales, al constituir condiciones materiales que posibilitan un mejor y más efectivo ejercicio de todos de las libertades. Tales derechos sociales no tienen diferencias cualitativas u ontológicas que permitan diferenciarlos de los derechos individuales.

Una perspectiva clásica de los derechos económicos, sociales y culturales plantea que ellos son relativos, en cuanto son de naturaleza prestacional y, por tanto, dependen de los recursos económicos del Estado para su realización, por lo que se presentan como normas programáticas o aspiraciones colectivas o fines plasmados en la norma constitucional, dependiendo de la situación específica de desarrollo relativa y situación económica de cada Estado, ${ }^{17}$ por tanto, tienen un carácter relativo, ya que la

17 Ver Hesse, Konrad. (1992). Escritos de Derecho Constitucional. (Madrid, Ed. Centro de Estudios Constitucionales), p. 65. Poyal Costa, Ana. (1991). "La eficacia de los derechos humanos frente a terceros". En Revista de Derecho Político No 34 (1991), Madrid, p. 213. MAYORGA LorCA, Roberto. (1990). Naturaleza Jurídica de los Derechos Económicos, Sociales y Culturales. segunda edición, (Santiago, Ed. Jurídica de Chile), p. 24. CARMOnA Cuenca, Encarnación. (1992). Las normas constitucionales de contenido social: delimitación y problemática de su eficacia jurídica. En Revista de Estudios Políticos $\mathrm{N}^{\circ}$ 76, Madrid, p.105. Hernández Valle, Rubén. (2002). “Los derechos prestacionales”. En Derechos Humanos y Constitución en Iberoamérica. Palomino Manchego, José y Remotti Carbonell, José Carlos (Coordinadores). (Lima, Ed. Universidad Mayor de San Marcos e Instituto Iberoamericano de Derecho Constitucional [Sección Peruana]), pp. 257 a 259. 
capacidad económica financiera de los países puede sufrir variaciones. Este sector de la doctrina considera que los derechos económicos, sociales y culturales constituyen parte de la política social que realizan los gobiernos dependiendo de los procesos económicos financieros del Estado, por lo que carecen de garantías efectivas.

Este enfoque de los derechos económicos, sociales y culturales se encuentra también entre los derechos individuales como el caso del derecho de acceso a la jurisdicción o tutela judicial y la defensa, que se encuentra asegurado en el Pacto Internacional de Derechos Civiles y Políticos de Naciones Unidas en su artículo 14 y en la Convención Americana sobre Derechos Humanos en su artículo 8, como asimismo en las garantías judiciales del artículo 25, para solo señalar algunos ejemplos. Ya que estos derechos implican al Estado estructurar y mantener un sistema judicial completo, proporcionar defensores financiados estatalmente, cuando la persona no tenga capacidad de pago de un defensor privado. Lo mismo ocurre con el derecho a la igualdad ante la ley, donde diversos tribunales constitucionales han eliminado cláusulas discriminatorias que han obligado a la administración a financiar prestaciones para los sectores discriminados arbitrariamente. En tal sentido, puede sostenerse que tanto los derechos individuales o civiles como los derechos sociales tienen una dimensión prestacional que implica gastos vía presupuestaria que requiere pago de tributos por parte de las personas.

No es así efectivo que exista una diferencia estructural básica de los derechos sociales como derechos prestacionales que implican acción positiva del Estado y gastos, frente a los derechos individuales como derechos de libertad y gratuidad, todos los derechos exigen fuertes desembolsos a los estados, todos los derechos individuales requieren para su aseguramiento que el Estado desarrolle un sistema de orden público, de tribunales que administren justicia, lo que no es gratis, ya que constituyen bienes públicos financiados por el Estado. La protección de la integridad física y psíquica, del derecho a la honra y la vida privada, implican una infraestructura judicial, policial, que son financiados con recursos públicos. Lo mismo ocurre con el derecho de propiedad, el que requiere de diversas prestaciones públicas, resguardo policial, sistema jurisdiccional para asegurar y garantizar el derecho, la creación de registros de propiedad, entre otros aspectos, además del respeto por parte de terceros. Todos los derechos son complejos y tienen dimensiones individuales y colectivas, negativas y positivas, de abstención y de prestación. No hay argumento válido para establecer una diferencia de naturalezas en esta materia entre derechos individuales y derechos sociales. Tanto los derechos individuales y sociales implican bienes públicos y costos públicos, sin perjuicio de eventuales tasas, aranceles que deban cancelar quienes son beneficiados por dichas prestaciones. Por otra parte, es necesario reconocer que hay derechos contenidos en los ordenamientos constitucionales y en los Pactos Internacionales de Derechos Económicos, Sociales y Culturales que tienen la misma estructura de los derechos civiles y que requieren la misma omisión de la potestad estatal de afectarlos o desconocerlos, como asimismo el mismo deber de garantía de los derechos civiles o individuales, como son la libertad para escoger establecimiento educacional, el derecho de negociación colectiva o el derecho de huelga, el derecho a elegir el sistema de salud, el derecho a no ser discriminado en el trabajo. 
Tampoco es predicable únicamente de los derechos sociales el que estos sean relativos y no puedan exigirse de todos, ya que en esa perspectiva, los derechos políticos dejarían de ser derechos humanos, ya que ellos son sólo exigibles respecto del Estado en que la persona es ciudadano, yo no ejerzo el derecho de sufragio respecto de cualquier Estado en el que me encuentre en un momento determinado. El hecho de que los derechos sociales sean exigibles respecto de un Estado determinado en situaciones específicas, no es un rasgo propio de los derechos sociales, sino que es compartido con los derechos políticos y algunos derechos individuales como el derecho a la jurisdicción y al debido proceso, a que este último lo podré exigir sólo del Estado en que me encuentro residiendo, y no respecto de tribunales de otros Estados, respecto de los cuales no tengo vinculación alguna.

Frente a quienes argumentan que los derechos sociales son derechos prima facie y no derechos definitivos, ya que no tendrían una configuración definitiva y una eficacia y vigencia garantizada, cabe señalar que ello es también una realidad en muchos derechos individuales, cuyos atributos van teniendo un desarrollo institucional progresivo, como ocurre entre otros, con los derechos a la igualdad ante la ley, el derecho al debido proceso, el derecho a la vida, entre otros, cuyo contenidos y límites evolucionan en el tiempo y de acuerdo a las diversas realidades culturales. El mismo enfoque analizado considera a tales derechos insuficientemente delimitados en el texto constitucional, lo que sólo se hacen concretamente exigibles cuando ellos son desarrollados por el legislador, de acuerdo con los recursos de que dispone el Estado, por lo que los jueces poco pueden hacer para exigirlos sin el respectivo desarrollo legislativo, así los enunciados constitucionales sobre derechos sociales no son justiciables. ${ }^{18}$ Esta perspectiva, debe rechazarse ya que todo derecho fundamental asegurado constitucionalmente tiene un contenido mínimo y un contenido esencial, de aplicación directa e inmediata, como asimismo dicho contenido constituye un límite al legislador. En la práctica la conformación y estructuración positiva de los derechos no obedece a razones técnicas, sino a decisiones políticas e ideológicas de los constituyentes.

Ante la argumentación de la diversa protección de los derechos, de la insuficiencia de ellos o la diversa modalidad que tal protección adopta, estableciendo una menor protección de los derechos sociales, ello nada dice sobre la naturaleza de un derecho fundamental. Cabe explicitar que un derecho tan importante como el derecho a la vida tiene esencialmente protección preventiva, ya que no hay protección del derecho frente al asesino, frente al régimen autocrático que asesina impunemente, la vida no puede recuperarse, ella sólo depende del respeto que se brinde al ordenamiento jurídico que la asegura, de la eficacia de las policías y de la cultura de los miembros de dicha sociedad. Los derechos tanto individuales como sociales no dependen sólo de su consagración normativa sino de su vigencia sociológica y de la eficacia de sus instituciones protectoras. Las diferentes formas de protección de los derechos (pro-

18 Martínez Estay, José Ignacio. (2003). “Valor e sentido dos direitos sociais”. En Direitos Humanos, Teorias e Práticas, (Coimbra, Almedina), p. 238. 
tección preventiva, reparadora o compensadora) y la mayor o menor facilidad de concreción de dicha protección o garantía no hace a un derecho fundamental más importante que otro o de mayor jerarquía, son todos igualmente derechos fundamentales o humanos y todos tienen su fundamento en la dignidad humana. Las modalidades de protección constituyen una decisión política e institucional que nada dice respecto de naturaleza e importancia de los respectivos derechos.

Los derechos sociales no se distinguen por ser de carácter programático frente a los derechos individuales que serían de eficacia directa e inmediata, sólo ocurre que los segundos tienen ya establecida su configuración legislativa y sus medios de protección en la legislación civil, procesal y penal, mientras que en el caso de los primeros ello se está concretando más recientemente, en la medida que hay voluntad política y toma de conciencia de su igual carácter de derechos fundamentales que los primeros, como asimismo, de su indispensable aseguramiento para hacer respetar un contenido de calidad de vida digna para todas las personas.

Además no es posible hacer una nítida diferenciación entre derechos civiles y políticos y derechos económicos sociales y culturales, ya que los primeros tienen también elementos de los segundos, en virtud de su indivisibilidad e interrelación. Así lo ha sostenido también la Corte Interamericana de Derechos Humanos, al realizar el análisis del artículo 19 referente a los derechos del niño, contenido en el artículo 19 de la Convención, precisando:

"En el análisis sobre el posible incumplimiento del Estado de sus obligaciones derivadas del artículo 19 de la Convención Americana, debe tenerse en consideración que las medidas de que habla esta disposición exceden el campo estricto de los derechos civiles y políticos. Las acciones que el Estado debe emprender, particularmente a la luz de las normas de la Convención sobre los Derechos del Niño, abarcan aspectos económicos, sociales y culturales, que forman parte principalmente del derecho a la vida y del derecho a la integridad personal de los niños". ${ }^{19}$

\section{LOS DERECHOS ECONÓMICOS, SOCIALES Y CULTURALES COMO DERECHOS FUNDAMENTALES EFICACES}

Frente a la perspectiva de quienes consideran a los derechos sociales solo como aspiraciones y no como derechos subjetivos, entregados a la libre discrecionalidad configurativa del legislador, junto con Pérez Luño, podemos afirmar su carácter de auténticos derechos, los que además, constituyen una garantía para la democracia y para el goce efectivo de los derechos individuales y políticos. ${ }^{20}$

La existencia de un derecho fundamental, como señala Alexy, implica que una persona dispone de un derecho a algo respecto de un sujeto obligado, sin que nece-

19 Corte Interamericana de Derechos Humanos, Caso "Instituto de reeducación del menor vs. Paraguay”, sentencia de 2 de septiembre de 2004, párrafo 149.

20 Ver Pérez Luño, Antonio. Los Derechos Fundamentales, p. 213. 
sariamente la satisfacción del contenido del derecho esté garantizado por una decisión judicial. ${ }^{21}$

Los derechos fundamentales o humanos constituyen una unidad indisoluble porque protegen la misma dignidad del ser humano. Ello hace a tales derechos, intrínsecamente interrelacionados e indivisibles, todos contribuyen a la misma proyección y desarrollo del ser humano, tanto los derechos civiles y políticos como los derechos económicos, sociales y culturales. Asimismo, no es posible considerar la participación activa e igual de todas las personas en la sociedad sin asegurar y garantizar los derechos sociales fundamentales y un nivel básico de justicia material, los cuales constituyen condiciones esenciales de un auténtico Estado Constitucional Democrático. ${ }^{22}$ La afirmación de los derechos sociales fundamentales, determina la perspectiva de que los jueces constitucionales deben garantizar el mínimo social especificado por las necesidades básicas asegurados constitucionalmente, lo que forma parte del contenido esencial de tales derechos, lo que enmarca la comprensión razonable de la concepción pública de justicia y de una existencia humanamente digna y saludable.

En tal perspectiva, los derechos fundamentales sociales se presentan en los sistemas jurídicos como el chileno como principios, reglas y parámetros hermenéuticos del orden constitucional, del mismo nivel jurídico y con la misma eficacia que los derechos civiles y políticos, encontrándose en un mismo artículo constitucional, el artículo 19 , fortalecidos por el artículo $5^{\circ}$, inciso segundo, de la Carta Fundamental, el cual los determina como límites de la soberanía, además de establecer el deber imperativo por parte de los órganos estatales de asegurarlos y promoverlos, tanto en su contenido constitucionalmente determinado como en sus atributos y garantías de los derechos asegurados por los tratados internacionales de derechos humanos ratificados por Chile y vigentes. A ello debe agregarse, el artículo 6 de nuestra Constitución que otorga fuerza normativa y aplicabilidad directa a los enunciados normativos constitucionales, salvo que el propio texto constitucional disponga otra cosa.

Los derechos fundamentales constituyen un sistema, un conjunto armónico, el cual tiene una doble fuente, el derecho constitucional y el derecho internacional, formando parte de un escenario complejo e interrelacionado, que asegura, protege, promueve y garantiza a los derechos en su conjunto indivisible de derechos civiles, políticos y sociales, lo que requiere compatibilizarlos, optimizarlos e interpretarlos bajo los postulados de progresividad y favor persona, como asimismo de prohibición de retroceso sin justificación y de interpretación restrictiva de las limitaciones de ellos legalmente establecidas, las que deben ser siempre necesarias, adecuadas y proporcionadas, asegurando la integridad del sistema jurídico, todo ello de acuerdo con el máximo de recursos disponibles.

21 Alexy, Robert. (1993). Teoría de los derechos fundamentales. (Madrid, Centro de Estudios Constitucionales), pp. 181-183.

22 Ver MichelmanN, Franck. (1979). “Welfare Rights in a Constitutional Democracy”. En Washington University Law Quaterly, Vol. 03. 1979 (Washington, Washington University Press), p. 34. 
Así puede sostenerse que es parte integrante del contenido esencial del Estado Social de Derecho y del constitucionalismo democrático contemporáneo el asegurar y garantizar condiciones de vida digna y saludable a todas las personas.

En el ámbito latinoamericano, los países que son partes de la Convención Americana sobre Derechos Humanos, saben que el artículo 26 de dicha Convención, posibilita la presentación de peticiones individuales en relación con derechos económicos, sociales y culturales, sobre lo cual se ha pronunciado la Corte Interamericana de Derechos Humanos en el caso "cinco pensionistas v/s Perú" en su sentencia de 28 de febrero de 2003, para solo señalar un ejemplo.

Los derechos económicos, sociales y culturales son derechos auténticos, como lo determina tanto el Pacto Internacional de Derechos Económicos, Sociales y Culturales de Naciones Unidas como el Protocolo de Derechos Económicos, Sociales y Culturales de la Convención Americana de Derechos Humanos aprobada en San Salvador y vigente en América. Tanto los derechos civiles pueden tener facetas de prestación como los derechos económicos, sociales y culturales presentan facetas de derechos de abstención del Estado y o de defensa, ${ }^{23}$ aunque en los derechos sociales la dimensión de prestación estatal tiene un carácter más marcado.

El Protocolo Adicional a la Convención Americana de Derechos Humanos en materia de Derechos Económicos, Sociales y Culturales, suscrito en la Asamblea General de la OEA, en San Salvador, República de El Salvador, el 17 de noviembre de 1988, en plena vigencia, reafirma la indisolubilidad de los derechos humanos, además de establecer que los Estados Partes se comprometen a adoptar las medidas necesarias tanto de orden interno como mediante la cooperación entre Estados, hasta el máximo de sus recursos disponibles y tomando en cuenta su grado de desarrollo para lograr progresivamente, y de conformidad con la legislación interna, la plena efectividad de los derechos económicos, sociales y culturales.

Los derechos protegidos por el Protocolo de San Salvador son similares a los protegidos por el Pacto Internacional de Derechos Económicos, Sociales y Culturales de Naciones Unidas, aun cuando el catálogo es mayor. Ellos son los siguientes: el derecho al trabajo (artículo 6); condiciones justas, equitativas y satisfactorias de trabajo (artículo 8); derechos sindicales (artículo 9); los derechos a la seguridad social, a la salud y a la alimentación (artículos 9, 10 y 12); el derecho a un medio ambiente sano (artículo 11, no comprendido en PIDESC); el derecho a la educación (artículo 13); el derecho a los beneficios de la cultura (artículo 14); los derechos a la constitución y protección de la familia y de la niñez (artículos 15 y 16); la protección de los ancianos y minusválidos (artículos 17 y 18, no comprendidos en el PIDESC).

23 Ver Abramovich, Víctor y Courtis, Christian. (2002). Los derechos sociales como derechos exigibles. (Madrid. Trotta), pp. 27-37. 
El Protocolo de San Salvador consagra un sistema de quejas o peticiones individuales ante el sistema interamericano, como lo establece su artículo 19.6.

En los casos que los derechos económicos, sociales y culturales no estén adecuadamente delimitados y configurados constitucionalmente, debe tenerse en consideración un contenido esencial de los mismos que constituye un parámetro para apreciar la constitucionalidad de las normas subconstitucionales y los actos de los agentes del Estado, sin perjuicio de considerarlos, además, como garantías institucionales, limitadoras de la acción legislativa. Por otra parte, debemos tener presente los contenidos mínimos para cada uno de tales derechos, que integra el contenido esencial de cada derecho sin agotarlo, los que han sido elaborados por el Comité de Derechos Económicos, Sociales y Culturales de Naciones Unidas, creado por el Consejo Económico y Social (ECOSOC) de la ONU para velar por la vigencia efectiva de tales derechos. ${ }^{24}$

La positivación constitucional constituye el primer paso para la efectividad y eficacia de los derechos económicos, sociales y culturales, como ocurre, asimismo, con los derechos individuales y políticos. Dicha positivación puede estar dada directa e inmediatamente en el texto constitucional al reconocerse los derechos económicos, sociales y culturales como derechos constitucionales o derechos fundamentales, adquiriendo la misma fuerza normativa que todas las disposiciones constitucionales, o por integrar el bloque constitucional de derechos como derechos implícitos, o derechos incorporados al texto constitucional por la vía de las fuentes del derecho internacional de los derechos humanos específicamente reconocidas e incorporadas al ordenamiento automáticamente o por el procedimiento que indica el propio texto constitucional.

En algunos casos los derechos económicos, sociales y culturales pueden estar suficientemente delimitados y configurados, determinando el sujeto pasivo de la obligación de su respeto y aseguramiento. Luego, es posible también garantizarlos como se hace con los derechos individuales. La exigencia al Estado es precisamente de que ellos sean efectivamente asegurados, respetados, protegidos y garantizados, ya que la garantía depende de una decisión política y económica del Estado.

El Tribunal Constitucional chileno ha asumido este reconocimiento pleno de los derechos económicos, sociales y culturales o derechos sociales fundamentales en sentencia del 26 de junio de 2008:

"Que la amplia mayoría de la doctrina nacional y extranjera reconoce que los derechos sociales, Ilamados también derechos de prestación o de la segunda generación, son tales y no simples declamaciones o meras expectativas, cuya materialización efectiva quede suspendida hasta que las disponibilidades presupuestarias del Estado puedan Ilevarlos a la práctica”. ${ }^{25}$

24 Ver Abramovich, Víctor y Courtis, Christian. (2002), pp. 89 y ss.

25 Sentencia del Tribunal Constitucional chileno de 26 de junio de 2008 , Rol $\mathrm{N}^{\circ} 976$, considerando $26^{\circ}$. 
El Tribunal Constitucional chileno asume la perspectiva que los derechos económicos, sociales y culturales fuera de ser verdaderos derechos al igual que los derechos civiles o individuales, presentan dimensiones tanto de defensa como prestacionales:

"Que resulta ineludible desvanecer la tesis contraria a que los derechos sociales sean realmente tales, aseverando (como lo hace Francisco J. Laporta, cit., pp. 304305) que poner en duda su "practicabilidad" de realización, es una idea confusa, porque esa "reserva de lo posible" Ileva a sostener que la Constitución ha de ser "desactivada", a causa de la imposibilidad económica del Estado de darles satisfacción, convirtiendo así en virtuales las cláusulas fundamentales que aseguran su materialización;

"Que la naturaleza jurídica de los derechos sociales en el Estado de Derecho Contemporáneo se halla abundante y certeramente configurada, testimonio de lo cual son los pasajes siguientes, extraídos de una obra bien conocida:

"Lo que tienen en común estos derechos no es tanto su contenido, esto es, la esfera de la vida social a que se refieren, sino más bien la posición jurídica que otorgan a su titular. De esta forma, los derechos sociales permitirían a sus titulares exigir ya no abstención por parte del Estado, como sucedía en los derechos de libertad, sino más bien una actuación positiva de éste en orden a su consecución. Por ello es más adecuado a su naturaleza la denominación de derechos de prestación". Reencarnación Carmona Cuenca: El Estado Social de Derecho en la Constitución, Consejo Económico y Social, España (2000), p. 150. Abundando en idéntico tópico se ha escrito que los derechos sociales son "Derechos de prestación (...) que suponen una acción positiva, normalmente de los poderes públicos, aunque también pueden ser los particulares más excepcionalmente, para ayudar a la satisfacción de necesidades básicas, que no pueden ser resueltas por la propia y excesiva fuerza del afectado (...)." Gregorio Peces-Barba Martínez: Curso de Derechos Fundamentales. Teoría General Universidad Carlos III, Madrid (1999), pp. 460;". ${ }^{26}$

Desde esta perspectiva, todos los derechos, tanto los individuales como los sociales generan obligaciones positivas y negativas al Estado, así puede establecerse un esquema de diversos niveles de obligaciones del Estado, entre las cuales están las obligaciones de respeto, las obligaciones de protección, las obligaciones de promoción y las obligaciones de garantía o satisfacción. ${ }^{27}$

Entre las obligaciones de respeto están las de no afectar con sus acciones la salud de las personas, el medio ambiente, el acceso a la educación, el derecho de huelga, la formación de sindicatos, de respeto a la irreversibilidad de los derechos sociales sin justificación, entre otros.

Sentencia del Tribunal Constitucional chileno de 26 de junio de 2008 , Rol $N^{\circ} 976$, considerandos $27^{\circ}$ y $28^{\circ}$.

27 Aвramovich, Víctor y Courtis, Christian. (2006). El umbral de la ciudadanía. El significado de los derechos sociales en el Estado social constitucional. (Buenos Aires, Editores del Puerto), p. 26. 
Entre las obligaciones de protección, se encuentran las de evitar que terceros afecten a través de acciones u omisiones los derechos sociales como no impedir la actividad sindical y el derecho de huelga, el derecho a las prestaciones de salud, las remuneraciones justas, el derecho al descanso, que no se discrimine en el ejercicio de los diversos ámbitos de los derechos sociales, entre otros.

Las obligaciones de promoción, las cuales en el ordenamiento constitucional chileno está expresamente establecida en el artículo $5^{\circ}$ inciso $2^{\circ}$ de la Constitución, exige realizar todas las acciones positivas para remover los obstáculos sociales, económicos, culturales y políticos que impidan el goce efectivo de los derechos, para lo cual de acuerdo con el artículo $2^{\circ}$ de la Convención Americana sobre Derechos Humanos, el cual establece la obligación del Estado Parte de "adoptar [...] las medidas legislativas o de otro carácter que fueren necesarias para hacer efectivos tales derechos y libertades".

Las obligaciones de garantía o satisfacción implican asegurar el derecho a las prestaciones mínimas exigidas por la dignidad humana y las obligaciones contenidas en el derecho internacional de los derechos humanos, el derecho al mínimo vital, el derecho de acceso a la educación, proveer de defensa legal letrada eficaz, entre otros aspectos.

Como señala Canotilho, los derechos subjetivos a prestaciones, aun cuando no sean concretizados suficientemente, pueden ser invocados judicialmente contra las omisiones inconstitucionales del legislador. La fuerza inmediatamente vinculante de los derechos fundamentales, puede y debe ser interpretada, en lo que respecta a los derechos prestacionales, en el sentido de fundamentar originariamente esos derechos, incluso cuando no hay imposición constitucional dirigida al legislador. ${ }^{28}$

Canotilho señalará que la fuerza dirigente y determinante de los derechos económicos, sociales y culturales invierte, desde luego, el objeto clásico de la pretensión jurídica fundada en un derecho subjetivo: "de una pretensión de omisión de los poderes públicos (derecho a exigir que el Estado se abstenga de interferir en los derechos, libertades y garantías) se transita a una prohibición de omisión (derecho a exigir que el Estado intervenga activamente en el sentido de asegurar prestaciones a los ciudadanos". ${ }^{29}$

En este ámbito, consideramos adecuado señalar que los derechos sociales, además de la prohibición de omisión como lo plantea Canotilho, también tiene una obligación negativa al igual que en los derechos individuales, la obligación de no dañar el derecho, como ocurre con el caso de la salud, el medio ambiente, entre otros.

Los derechos económicos, sociales y culturales, al igual que los derechos civiles y políticos, deben tener las características de universalidad, equidad y calidad.

28 Canotilho, Constitucao Dirigente, pp. 370-371.

29 Canotilno. Constitucao Dirigente, Ibídem, p. 365. 
La universalidad deriva de la conceptualización como derecho humano o derecho fundamental, ya que este debe estar asegurado a todas las personas.

La equidad indica que el financiamiento del servicio debe provenir esencialmente de tributos y no del pago de sus usuarios, salvo en el caso de que ellos tengan capacidad económica suficiente, ya que asî se eliminan las arbitrariedades en el acceso a las prestaciones. ${ }^{30}$

La calidad es una condición necesaria de la eficacia del sistema y de la necesidad de igualación de oportunidades de vida que debe asegurar el Estado.

Puede sostenerse que no es posible actualizar y hacer efectiva la libertad si su establecimiento y sus respectivas garantías no van acompañadas conjuntamente de unas condiciones existenciales básicas que hagan posible su ejercicio real y efectivo, como afirmaba ya García Pelayo, ${ }^{31}$ agregando que sin el mínimo necesario para la existencia cesa la posibilidad de vida digna y desaparecen las condiciones para la práctica de la libertad. Ello lleva a sostener junto a Ricardo Lobo que la dignidad humana y las condiciones materiales de existencia digna no pueden sino ser reconocidas y garantizadas en un contenido básico y esencial, no pudiendo retroceder bajo dicho contenido esencial. ${ }^{32}$

Por otra parte, Imbert sostiene que la vulneración de los derechos económicos, sociales y culturales son justiciables a través de impugnaciones contenciosas o de demandas de indemnización, ${ }^{33}$ lo que se concreta no solo en el plano interno de cada Estado sino también ante los organismos internacionales que conocen de las peticiones o quejas en la materia.

\section{LOS SUJETOS OBLIGADOS POR LOS DERECHOS SOCIALES FUNDAMENTALES}

Los obligados frente a los derechos sociales fundamentales dependen de las características de la norma jurídica constitucional y de la obligación jurídica. Los obligados dependen, como señala Arango, de la interpretación de las normas sobre derechos fundamentales y de la asignación posterior de las obligaciones correlativas. ${ }^{34}$

30 CARBonell, Miguel. (2001). La Constitución en serio. Multiculturalismo, igualdad y derechos sociales. México, Ed. Porrúa - Universidad Nacional Autónoma de México, p. 181.

31 García Pelayo, Manuel. (1980). Las transformaciones del Estado contemporáneo. Madrid, Alianza Editorial, p. 26.

32 Lово TORRES, Ricardo. (2003). "La metamorfosis de los derechos sociales en Mínimo Existencial”. En Sarlet, Ingo W. (organizador), Direitos Fundamentais Sociais: estudios de direito constitucional, internacional e comparado. (Río de Janeiro, Ed. Renovar), p. 26.

33 IMBERT, Pierre-Henri. (1989). Droits des pauvres, pauvre droit(s)? Reflexions sur les droits économique, sociaux et culturels. En Revue de Droit Public et de la Science Politique en France et à l'étranger, $\mathrm{N}^{\circ} 1$, 1989, París, Francia, Ed LGDJ, p. 742.

34 Arango, Rodolfo. El concepto de derechos sociales fundamentales. (2005), p. 90. 
La regla general es que el obligado respecto a los derechos sociales fundamentales es la sociedad representada por el Estado. Los individuos solo pueden considerarse obligados por la eficacia horizontal indirecta de los derechos fundamentales, lo que remite a la vinculación de las autoridades publicas a los derechos fundamentales y el efecto de irradiación de éstos sobre el derecho infraconstitucional. Así son obligados directos de los derechos fundamentales sociales el legislador, el gobierno y la administración y la judicatura ordinaria y constitucional, ya que todos los órganos y autoridades estatales deben respetar y promover los derechos fundamentales como establece el inciso $2^{\circ}$ del artículo $5^{\circ}$ de nuestra Constitución. También lo son las personas que deben respetar los derechos sociales en cuanto normas constitucionales de aplicación directa e inmediata que irradian y vinculan a todos los actos privados y contratos como lo ha determinado nuestro Tribunal Constitucional.

\section{EL OBJETO DE LOS DERECHOS ECONÓMICOS, SOCIALES Y CULTURALES O DERECHOS SOCIALES FUNDAMENTALES}

El objeto del derecho fundamental coincide con el objeto de la norma jurídica que se homologa con el objeto de la obligación jurídica. El objeto del derecho fundamental son las acciones $u$ omisiones de otro u otros que constituyen los atributos del derecho fundamental y cuyo cumplimiento es indispensable para la realización del derecho.

El objeto de un derecho social fundamental puede ser tanto una acción (caso de un derecho prestacional, de un derecho de protección o de acceso a la jurisdicción) como una omisión (en caso de un derecho de defensa) por parte del obligado.

Para el cumplimiento de los derechos sociales fundamentales, el Estado puede utilizar como instrumento la realización de una acción fáctica o una acción normativa, estableciendo obligaciones generales que posibilitan indemnizaciones laborales, vacaciones laborales, derechos de pre y post parto con remuneraciones, etc. El Estado puede escoger así los medios para asegurar los derechos sociales fundamentales, existiendo una obligación de garantía que se mantiene como un correlativo del derecho positivo general.

El cumplimiento por parte del Estado de las obligaciones correlativas frente a los derechos sociales fundamentales dependen de las posibilidades jurídicas y fácticas de realización de las exigencias demandadas por el titular del derecho fundamental que debe ser asegurado, garantizado y promovido, lo que debe ser argumentado. ${ }^{35}$

El Estado tiene así una doble función respecto de los derechos sociales, tiene el deber de respetar las obligaciones que generan los derechos y los límites que ellos aseguran, como asimismo la obligación de promoverlos, vale decir, de eliminar los

35 Ver Arango, Rodolfo. El concepto de derechos sociales fundamentales. (2005), pp. 107-113. 
obstáculos que impidan su realización efectiva con todos los medios de que dispone, como asimismo, los órganos y autoridades públicas, dentro del ámbito de sus competencias, tienen la obligación de proteger los derechos sociales de las personas frente a afectaciones provenientes de agentes privados. ${ }^{36} \mathrm{~A}$ su vez, los miembros de la sociedad en sus relaciones de derecho privado quedan también vinculados por el respeto, promoción y no discriminación en materia de derechos sociales fundamentales.

\section{LAS GARANTÍAS DE LOS DERECHOS ECONÓMICOS, SOCIALES Y CULTURALES}

La búsqueda de procedimientos eficaces que lleven a una garantía real de todos los derechos humanos, los individuales y los sociales, los cuales son indivisibles, contribuyendo todos al desarrollo y concreción de la dignidad humana, es uno de los esfuerzos más trascendentes en que están empeñados los estados nacionales como la comunidad internacional, el derecho interno como el derecho internacional de los derechos humanos, en un trabajo complementario, convergente y progresivo.

La obligación de los órganos del Estado de respetar y garantizar los derechos, lo ha señalado directa y claramente la Corte Interamericana de Derechos Humanos como intérprete último de tales convenciones en el ámbito regional: "[...] es la de "garantizar" el libre y pleno ejercicio de los derechos reconocidos en la convención a toda persona sujeta a su jurisdicción. Esta obligación implica el deber de los Estados Partes de organizar todo el aparato gubernamental y, en general, todas las estructuras a través de los cuales se manifiesta el ejercicio del poder público, de manera tal que sean capaces de asegurar jurídicamente el libre y pleno ejercicio de los derechos humanos. Como consecuencia de esta obligación, los Estados deben prevenir, investigar y sancionar toda violación de los derechos reconocidos por la convención y procurar, además, el restablecimiento, si es posible, del derecho conculcado y, en su caso, la reparación de los daños producidos por la violación de los derechos humanos" (caso Godinez Cruz. Sentencia de fecha 20 de enero de 1989. Serie C, número 5, párrafo 166).

\subsection{Las garantías internacionales de los derechos fundamentales}

Las garantías de los derechos pueden ser clasificadas en una primera aproximación, en garantías nacionales y garantías internacionales, en el entendido que las garantías no se agotan en el plano interno del Estado, sino que trascienden al plano internacional o supranacional a través de distintas instituciones y mecanismos, para ello existen el Pacto Internacional de Derechos Económicos, Sociales y Culturales de Naciones Unidas y sus

36 Ver Pisarello, Gerardo. (2001). "Del Estado Social legislativo al Estado social Constitucional: por una protección compleja de los derechos sociales”. En Revista Isonomía N 14, 2001, (Madrid, Cedam), p. 94. 
órganos de supervigilancia, el Comité de Derechos Económicos, Sociales y Culturales de Naciones Unidas). Asimismo, en el plano latinoamericano existe el sistema interamericano integrado por la Convención Americana de Derechos Humanos, que contempla la protección de derechos sociales en su artículo 26 y el Protocolo de San Salvador que asegura y protege específicamente los derechos económicos, sociales y culturales, estableciendo un mecanismo de peticiones o quejas individuales ante el sistema interamericano de protección de derechos, la Comisión Interamericana y la Corte Interamericana de Derechos Humanos, de acuerdo a lo dispuesto en su artículo 19.6, para los derechos sindicales y el derecho a la educación. Asimismo, los tribunales nacionales deben considerar los contenidos de cada derecho en el ámbito de contenido mínimo precisado por el Comité de Derechos Humanos de Naciones Unidas.

En esta materia deben tenerse presente las directrices de Maastricht sobre violaciones a los Derechos Económicos, Sociales y Culturales desarrollados bajo el alero de la Comisión Internacional de Juristas entre el 22 y 26 de enero de 1997. En dichas directrices se establecieron las violaciones de derechos mediante actos de comisión y mediante actos de omisión.

Dentro de las violaciones mediante actos de comisión, se señalan las siguientes: “(a) La anulación o suspensión de cualquier legislación que sea necesaria para seguir ejerciendo un derecho económico, social y cultural que esté vigente en ese momento;

(b) La denegación activa de estos derechos a determinados individuos o grupos mediante cualquier forma de discriminación legislada o impuesta;

(c) El apoyo activo a cualquier medida adoptada por terceros que sea contraria a los derechos económicos, sociales y culturales;

(d) La aprobación de cualquier legislación o política que sea claramente incompatible con las obligaciones legales preexistentes relativas a estos derechos, salvo cuando esto se hace con el propósito y efecto de aumentar la igualdad y mejorar la realización de los derechos económicos, sociales y culturales de los grupos más vulnerables;

(e) La adopción de cualquier medida que sea intencionalmente regresiva y que reduzca el nivel de protección de cualquiera de estos derechos;

(f) La obstaculización o interrupción intencional de la realización progresiva de un derecho previsto en el Pacto, salvo cuando el Estado actúa dentro de los parámetros de una limitación estipulada en el Pacto o debido a la falta de recursos disponibles o fuerza mayor;

(g) La reducción o desviación de un gasto público específico, cuando dicha reducción o desviación resulta de la imposibilidad del goce de estos derechos y no sea acompañada por la adopción de medidas adecuadas que aseguren a todos la subsistencia mínima”

Dentro de las violaciones mediante actos de omisión las directrices de Maastricht: “(a) La no adopción de las medidas adecuadas estipuladas en el Pacto; 
(b) La no modificación o revocación de cualquier legislación que sea claramente inconsistente con una obligación prevista en el Pacto;

(c) La no aplicación de legislaciones o ejecución de políticas destinadas a hacer efectivas las disposiciones en el Pacto;

(d) La no regulación de actividades de particulares o grupos para evitar que éstos violen los derechos económicos, sociales y culturales;

(e) La no utilización al máximo de los recursos disponibles para lograr la plena realización de Pacto;

(f) La falta de vigilancia de la efectividad de los derechos económicos, sociales y culturales, incluyendo la elaboración y aplicación de criterios e indicadores para evaluar el acatamiento;

(g) La no eliminación inmediata de los obstáculos que debe eliminar para permitir la efectividad inmediata de un derecho garantizado en el Pacto;

(h) La no aplicación inmediata de un derecho que debe tener efectividad inmediata conforme al pacto;

(i) El no cumplimiento de la norma mínima internacional de realización cuando dicho cumplimiento quede dentro de sus posibilidades;

(j) Cuando el Estado, al celebrar convenios bilaterales o multilaterales con otro Estado y con organizaciones internacionales o empresas multinacionales, no tenga en cuenta sus obligaciones legales internacionales en la esfera de los derechos económicos, sociales y culturales".

\subsection{Las garantías nacionales}

Las garantías nacionales pueden ser clasificadas en garantías genéricas y específicas como ya hemos analizado en el capítulo II del tomo I de esta obra.

Entre las garantías genéricas nacionales se encuentra, en primer lugar, la afirmación de la dignidad humana, que constituye el fundamento de todos los derechos fundamentales, tanto los derechos individuales y políticos, como de los derechos económicos, sociales y culturales. Asimismo, el aseguramiento constitucional de los derechos, con las consiguientes obligaciones de los órganos estatales de respeto, protección y promoción constituye otra garantía básica de ellos.

La segunda la constituye la existencia y vigencia efectiva de una «República Democrática» donde las ideas de pluralismo y participación definen la fórmula política, repercutiendo en el tema de las garantías de diversos ángulos: un poder legislativo representativo del cuerpo político de la sociedad, el que ocupa un lugar importante en la elaboración de normas y el aseguramiento de los derechos y por el reconocimiento de los derechos de participación esenciales a una visión integral de los derechos fundamentales.

Dentro de las garantías genéricas el asumir la concepción del estado de derecho democrático y el establecimiento de la promoción por parte del Estado de la igualdad 
de oportunidades para participar en todos los planos de la vida nacional, afianzan una interpretación de los derechos en su conjunto indivisible e inseparable, en una perspectiva favor persona y favor débiles que lleva a dotar de la máxima efectividad posible a los derechos sociales.

Las separaciones de funciones entre los diversos órganos estatales con la consiguiente distribución de funciones y un sistema de pesos y contrapesos contribuye a evitar los abusos y desviaciones de poder y las discriminaciones arbitrarias en el aseguramiento y ejercicio de los derechos sociales, estableciéndose los sistemas de control recíproco y las instituciones de control administrativo a través de auditorías, controles de legalidad y diversos otros mecanismos, entre los cuales se encuentran también los defensores del pueblo o de las personas, según la denominación que reciban en cada Estado.

Otra garantía genérica es el derecho a la información pública que tienen los ciudadanos respecto de las actuaciones del gobierno y la administración, lo cual es recogido por los ordenamientos jurídicos. En el caso chileno dicho derecho de acceso a la información pública y el consiguiente principio de transparencia está asegurado directamente por las bases de la institucionalidad, en el artículo $8^{\circ}$ de la Constitución. Este derecho posibilita el conocimiento y evaluación de los indicadores de las políticas públicas y sus resultados; el contenido de dichas políticas públicas, con sus respectivos objetivos, plazos de realización, medios y recursos disponibles.

La igualdad y no discriminación en materia de prestaciones sociales constituye una obligación que deriva del artículo 2.2. del Pacto Internacional de Derechos Económicos, Sociales y Culturales de Naciones Unidas, el cual determina:

"los Estados Partes en el presente Pacto se comprometen a garantizar el ejercicio de los derechos que en él se enuncian, sin discriminación alguna por motivos de raza, color, sexo, idioma, religión, origen nacional o social, posición económica, nacimiento o cualquier otra condición social".

\subsubsection{Las garantías específicas.}

Estas garantías pueden clasificarse en garantías normativas, garantías de control y fiscalización, garantías de interpretación y garantías jurisdiccionales.

9.2.1.1. Las garantías normativas. Las garantías normativas hacen referencia al principio de legalidad en sentido amplio, concentrando su significado en los derechos fundamentales, regulando su desarrollo y aplicación, como su reforma, como asimismo, a los límites a la capacidad de regular y limitar los derechos que tiene el legislador.

a) El principio de reserva legal. El principio de reserva legal y del contenido esencial de los derechos protegen por igual a los derechos civiles y políticos como a los derechos económicos, sociales y culturales. 
Con el concepto de reserva de ley se definen sectores y materias que están reservados exclusiva y completamente a la ley y excluyendo su regulación por parte de la administración.

De esta manera, no sólo se reserva al legislador, sino que también se limita la libertad de acción del legislador en la regulación de los derechos fundamentales, el cual queda obligado a regular las materias objeto de dicha reserva.

El principio de reserva legal no excluye las remisiones que el legislador puede hacer a la autoridad administrativa para reglamentar las leyes, pero esta regulación reglamentaria está claramente subordinada a los parámetros definidos por la ley.

Así, el sentido último de la reserva de ley es «asegurar que la regulación de los ámbitos de libertad que corresponden a los ciudadanos dependa exclusivamente de la voluntad de sus representantes, por lo que tales ámbitos han de quedar exentos de la acción del ejecutivo y, en consecuencia, de sus productos normativos propios, que son los reglamentos", como señala el Tribunal Constitucional español en su sentencia 83/1984.

La reserva de ley constituye así una limitación a la potestad reglamentaria del Presidente de la República y un mandato específico del constituyente al legislador para que sólo este regule ciertas materias en sus aspectos fundamentales.

La reserva de la ley asegura que la elaboración, debate y aprobación de ciertas materias se produzca mediante el procedimiento legislativo parlamentario. Se trata que sea el Congreso Nacional el que regule las materias que el constituyente le ha dado mayor trascendencia e importancia sometiéndolos al procedimiento legislativo que se basa en los principios de publicidad, contradicción y debate, reforzándose respecto de esas materias la garantía del pluralismo político. Además, en una perspectiva en que todos los sectores políticos representativos del país son escuchados, se puede lograr un mejor orden de prelación material y temporal, una mayor justificación racional y una definición pública más transparente del bien común.

La reserva de ley como reserva de lo esencial se transforma en último caso, en reserva de sentencia, ya que será el Tribunal Constitucional el que determinará dicho criterio en cada hipótesis normativa.

La frontera de la reserva de ley depende de la ordenación y de las relaciones existentes en cada Estado entre el Congreso y el Gobierno en el derecho constitucional vigente, definidas por cada Carta Fundamental en cada momento histórico concreto, dependiendo del ámbito de tareas que el Estado reivindica para sí mismo en función de sus respectivas metas.

El principio de reserva de ley se refuerza en el caso en que el Constituyente reserva la regulación de la materia al legislador de quórum especial en cuyo caso se requiera de mayor quórum y, por tanto, de mayor acuerdo parlamentario 
La reserva de ley es una norma de competencia y una regla de rechazo. Es una norma de competencia, ya que para que los enunciados normativos puedan ser considerados válidos deben reunir como condiciones mínimas que procedan de un determinado órgano, que hayan sido creados de acuerdo a determinado procedimiento y que traten sobre una determinada materia. A su vez, la reserva de ley es una regla de rechazo, entendiendo por tal, todo enunciado jurídico de tipo cualificatorio que señala que determinados enunciados no tienen carácter jurídico o no pertenecen a un cuerpo jurídico. Así, en relación a la reserva de ley, se califican como enunciados no jurídicos los que no reúnen los siguientes requisitos como mínimo: que no procedan de un determinado órgano (Congreso), que no sean creados de acuerdo a un determinado procedimiento (procedimiento legislativo) y que no traten de una cierta materia (materia de ley). ${ }^{37}$

También cabe plantearse cuál es el objeto de la legislación de desarrollo de los derechos constitucionales. En nuestra opinión, lo que se desarrolla no es el derecho sino el precepto constitucional en el que el derecho se asegura, determinando sus alcances y sus límites. Así el legislador puede centrar su acción de desarrollo de los preceptos constitucionales que contienen derechos en dos fines. El primero, estableciendo una modificación normativa no contraria a la Constitución de algunos de los elementos configuradores del derecho (titular, destinatario, objeto), lo que afecta el ejercicio del derecho, por tanto, puede hacerse cuando la Constitución lo autoriza. El segundo fin puede ser el de completar la configuración del derecho o configurarlo cuando el constituyente no lo ha hecho, determinando su contenido o la fijación de la forma de su ejercicio, como asimismo, las garantías procesales del mismo.

De esta forma, por regla general, el estatuto de un derecho fundamental está constituido por normas constitucionales, del derecho internacional en sus diversas fuentes y normas legales.

Por último, cabe preguntarse qué sucede con los derechos que están garantizados constitucionalmente, sin que exista una reserva de ley que les afecte de manera especial. En tales casos, hay dos tipos de respuesta, la primera, que ellos no pueden ser limitados por el legislador, ya que así lo ha deseado el constituyente, fortaleciendo el estatuto constitucional de tales derechos o, segunda, el legislador puede regular tales derechos aplicando justificaciones determinadas por la propia Constitución, tales como los derechos de terceros o la existencia de bienes jurídicos de rango constitucional. En esta encrucijada optamos por la segunda alternativa, la que consideramos más coherente con el sistema constitucional de derechos fundamentales y la idea que los derechos forman un sistema dentro del cual ellos se interrelacionan y limitan recíprocamente.

Por otra parte, es necesario que, como señala Ferrajoli, que "Las leyes en materia de servicios públicos no solo establecieran contenidos y presupuestos de cada derecho social, sino que identificasen también a los sujetos de derecho público investidos de las

37 Gavara De Cara, Juan Carlos. (1994). Derechos Fundamentales y Desarrollo legislativo. Ed. Centro Estudios Constitucionales. Madrid, España, p. 141. 
correlativas obligaciones funcionales; que toda omisión o violación de tales obligaciones, al comportar la lesión no ya de meros deberes o a lo sumo de intereses legítimos sino de derechos subjetivos, diera lugar a una acción judicial de posible ejercicio por el ciudadano perjudicado; que la legitimación activa fuera ampliada, en los derechos sociales de naturaleza colectiva, también a los nuevos sujetos colectivos, no necesariamente dotados de personalidad jurídica, que se hacen portadores de los mismos; que, en suma, junto a la participación política en las actividades de gobierno sobre las cuestiones reservadas a la mayoría, se desarrollase una no menos importante participación judicial de los ciudadanos en la tutela y satisfacción de sus derechos como instrumentos tanto de autodefensa como de control en relación a los poderes públicos". ${ }^{38}$

Asî, cuando existe una adecuada delimitación del derecho social y se definen los sujetos activos y pasivos del mismo, ellos pueden ser exigidos en forma imperativa y con cumplimiento inmediato. Como ha señalado la Corte Constitucional de Colombia en Sentencia T-042 de febrero 7 de 1996:

"Cuando los derechos prestacionales, genéricamente consagrados, son asumidos por el Estado en forma directa, y se ha definido legal y reglamentariamente como destinatario de la prestación específica a un grupo de personas determinadas, tales derechos se truecan en subjetivos y, en consecuencia, pueden ser exigidos en forma inmediata por sus titulares, a través de la vía judicial prevista para el caso por el legislador". ${ }^{39}$

Otro ámbito de la garantía normativa de reserva legal es aquella consignada tanto en los textos constitucionales como también en la Convención Americana de Derechos Humanos, que prohíbe que a través de la delegación legislativa se puede afectar el régimen jurídico de los derechos y garantías constitucionales.

Finalmente, algunos ordenamientos constitucionales establecen que la regulación legislativa de derechos fundamentales sólo puede hacerse a través de leyes de quórum calificado que implican al menos la mayoría en ejercicio de los componentes del parlamento o de cada una de sus ramas, tanto para la regulación de desarrollo como restrictiva del ejercicio de derechos fundamentales.

Por último, es necesario tener presente que hoy todos los poderes estatales en sus actuaciones deben tener presente la tarea de asegurar, respetar, promover y fanatizar los derechos fundamentales, la que recae con mayor fuerza en los órganos colegisladores (gobierno y parlamento), los cuales se encuentran vinculados por tales obligaciones jurídicas establecidas por la Constitución y el derecho internacional de los derechos humanos.

38 Ferrajoli, L. (2000). Quali sono i diritti fondamentali?, En Vitale, E. (Editor). Diritti Umani e diritti delle minoranze, (Turín, Ed. Rosenberg \& Sellier), pp. 917-918.

39 Herrera Vergara, Hernando. (2000). Acción de Tutela y derechos prestacionales. En Jurisdicción Constitucional en Colombia. Santafe de Bogotá, Colombia, Ed. Corte Constitucional y otros, p. 293. 
Esta vinculación del legislador por los derechos llevó a Krüger a afirmar que "Antes los derechos fundamentales sólo valían en el ámbito de la ley, hoy las leyes sólo valen en el ámbito de los derechos fundamentales". ${ }^{40}$

b) El respeto al contenido esencial de los derechos. La reserva de ley para regular los derechos se ve fortalecida por la obligación que tiene el legislador de no afectar los derechos en su esencia.

El legislador debe respetar la naturaleza jurídica de cada derecho que preexiste al momento legislativo y a los intereses jurídicamente protegidos. Así el contenido objetivo intrínseco de cada derecho constituye una entidad previa a la regulación legislativa.

El contenido esencial de cada derecho constituye la sustancia o propiedades básicas del derecho que no pueden ser afectadas por el legislador. El contenido esencial de los derechos es una frontera, un límite, que el legislador no puede sobrepasar, si lo hace incurre en inconstitucionalidad.

La garantía del contenido esencial de los derechos, con independencia del sentido que se le atribuya, "debe ser entendida como una regla de rechazo, es decir como un enunciado jurídico que califica como inválidos otros enunciados jurídicos". ${ }^{41}$

Como señala Otto y Pardo la garantía del contenido esencial de los derechos constituye el límite de los límites (Schranken-Schranken); "porque limita la posibilidad de limitar, porque señala un límite más allá del cual no es posible la actividad limitadora de los derechos fundamentales y de las libertades públicas", ${ }^{42}$ posición que apoya y fortalece el carácter directamente normativo de los derechos fundamentales.

A su vez, sostenemos que la garantía del contenido esencial de los derechos tiene un carácter declarativo y no constitutivo, ya que no crea ningún límite nuevo a los límites que sea diferente del que se desprende del valor constitucional respectivo del o de los derechos fundamentales en consideración determinado por el texto constitucional o el bloque constitucional de derechos, sólo determina un tope a la actividad legislativa limitadora de los derechos.

La garantía del contenido esencial de los derechos se proyecta sobre todos los derechos constitucionales, también sobre los derechos económicos, sociales y culturales y no solo sobre los derechos individuales. Al respecto cabe señalar el pronunciamiento del Comité de Derechos Económicos, Sociales y Culturales de Naciones Unidas en su Observación General $N^{\circ} 3$.

40 KRÜGER, Herbert. (1950). Die Einschrrükimg von Grundrechten nach Grungesetz, en Deutsches Verawaltungsblatt, p. 626.

41 Gavara De Cara, Juan Carlos. (1994). Derechos fundamentales y desarrollo legislativo, p. 142.

42 De Otto y PARDo, Ignacio. (1988). "La regulación del ejercicio de los derechos y libertades. La garantía del contenido esencial en el artículo 53.1 de la Constitución”, en Martín Retortillo, Lorenzo y De OtTo y PARDo, Ignacio. Derechos Fundamentales y Constitución. (Madrid, Cuadernos Civitas Derecho Constitucional), ob. cit., p. 126. 
Asimismo, nuestro Tribunal Constitucional ha asumido esta posición en su sentencia del 26 de junio de 2008:

"Que si bien la doctrina y jurisprudencia comparadas han señalado que los derechos sociales requieren la concretización legal de su contenido, también han realzado que la Constitución establece, en relación con ellos, un núcleo esencial, indisponible por el legislador. En tal sentido, se ha afirmado que:

"Existen derechos de contenido social que están regulados en las Constituciones, desde luego en la nuestra como (alude a la Española de 1978) derechos fundamentales directamente exigibles. Es el caso, por ejemplo, de la enseñanza básica declarada en el artículo 27.4 como obligatoria o gratuita. Aun dentro del ámbito del Capítulo III del Título Primero de la Constitución, dedicado a los principios rectores de la política social y económicas, se encuentran derechos de carácter social que formulan estándares mínimos que, desde luego, tienen que ser respetados por leyes y pueden ser directamente invocados: las vacaciones periódicas retribuidas (artículo 40.4), el régimen público de la seguridad social para todos los ciudadanos que ofrezcan prestaciones "suficientes" ante situaciones de necesidad, especialmente en el caso del desempleo (artículo 41), se refiere a prestaciones que tienen que sea necesariamente atendidas. No puede no existir una política de protección a la salud (artículo 43), etc”. (Santiago Muñoz Machado: Tratado de Derecho Administrativo y Derecho Público General, Madrid, Editorial Thomson-Civitas (2004), p. 1026);". 43

En el mismo sentido, el artículo $4^{\circ}$ del Pacto Internacional de Derechos Económicos, Sociales y Culturales, precisan que las limitaciones o restricciones legales al ejercicio de los derechos consagrados en el respectivo instrumento jurídico internacional solo pueden establecerse en la "medida compatible con la naturaleza" del derecho reglamentado.

Asimismo, encontramos en los Principios de Limburgo, el principio 56, el cual determina: "La restricción 'compatible con la naturaleza de esos derechos' requiere que una limitación no deberá interpretarse o aplicarse en menoscabo de la naturaleza intrínseca de un determinado derecho".

Por otra parte, como se desprende del Pacto Internacional de Derechos Económicos, Sociales y Culturales de Naciones Unidas, la obligación de adopción de medidas inmediatas para la realización de los derechos sociales que exige la utilización del máximo de recursos disponibles, incluyendo la cooperación internacional, además del mínimo no susceptibles de afectación en cada derecho forman parte del contenido esencial del derecho, asimismo las obligaciones básicas o mínimas que exige el Pacto involucran componentes prestacionales específicos, por lo que la exigibilidad no se reduce solamente a obligaciones negativas.

43 Sentencia del Tribunal Constitucional chileno, 26 de junio de 2008 , Rol $\mathrm{N}^{\circ} 976$, considerando $30^{\circ}$. 
El contenido mínimo esencial de los derechos sociales constituye un contenido inderogable con independencia de la situación económica que enfrenten los Estados Parte. En efecto, el Comité, a partir de la Observación General sobre el Derecho a la salud, establece una prohibición absoluta de incumplir las obligaciones básicas que se consideran inderogables. El PIDESC considera que el contenido mínimo de los derechos sociales es inderogable, lo que impide todo incumplimiento en toda circunstancia, constituyendo un mínimo de carácter absoluto que un Estado Parte debe siempre asegurar siendo de cumplimiento inmediato.

En este sentido debemos tener presente la Observación General $N^{\circ} 3$ del Comité de Derechos Económicos, Sociales y Culturales de la ONU, cuyo párrafo 10, determina que "corresponde a cada Estado Parte una obligación mínima de asegurar la satisfacción de por lo menos niveles esenciales de cada uno de los derechos”.

9.2.1.2. Las garantías de interpretación. Las garantías de interpretación se refieren a los mecanismos destinados a garantizar que la interpretación de los derechos se haga para favorecer su ejercicio y su disfrute. En tal sentido está la obligación de los órganos del Estado, todos y cada uno de ellos, de respetar y de promover los derechos esenciales establecidos en la Constitución y también, en los tratados de derechos humanos ratificados, como asimismo, el deber del Estado de promover la integración armónica de todos los sectores sociales y asegurar la igualdad de oportunidades para participar en la vida nacional en todas y cada una de sus dimensiones: política, social, cultural, económica, lo que obliga a remover todos los obstáculos que impidan o dificulten tales objetivos.

La vinculación directa a la Carta Fundamental de todos los órganos y personas, lo que significa que su actuación nunca puede afectar el ejercicio de los derechos más allá de lo que autoriza el propio texto constitucional y las obligaciones derivadas de los tratados en materia de derechos humanos que el Estado ha ratificado y se encuentran vigentes, los cuales también contienen normas interpretativas en materia de derechos.

Los principios "favor homine" "pro cives" o "favor persona" que implica la aplicación de aquella norma de derecho interno o de derecho internacional incorporada válidamente al derecho interno que mejor asegure y garantice el ejercicio de los derechos.

La consagración del principio de progresividad de los derechos, establecido expresamente en el artículo 2.1. del Pacto Internacional de Derechos Económicos, Sociales y Culturales, el cual dispone: "Cada uno de los Estados Partes en el Presente Pacto se compromete a adoptar medidas, tanto por separado como mediante la asistencia y cooperación internacionales, especialmente económicas y técnicas, hasta el máximo de los recursos de que disponga, para lograr progresivamente, por todos los medios apropiados, inclusive en particular la adopción de medidas legislativas, la plena efectividad de los derechos aquí reconocidos". 
El principio de progresividad ha sido determinado por la Asamblea General de la OEA, el 7 de junio de 2005, al aprobar las Normas para la confección de los informes periódicos previstos en el artículo 19 del Protocolo de San Salvador, en el artículo 5.1 determinando "a los fines de este documento, por el principio de progresividad se entenderá el criterio de avance paulatino en el establecimiento de las condiciones necesarias para garantizar el ejercicio de un derecho económico, social y cultural”.

Asimismo, la Comisión Interamericana de Derechos Humanos, en relación al artículo 26 de la Convención Americana sobre Derechos Humanos, ha establecido que "El principio de desarrollo progresivo establece que tales medidas se adopten de manera tal que constante y consistentemente promuevan la plena efectividad de esos derechos". ${ }^{44}$

Por su parte, la Corte Interamericana sobre Derechos Humanos, sobre la progresividad en materia de Derechos Económicos, Sociales y Culturales, en el caso Cinco Pensionistas Vs. Perú, ha establecido:

"Su desarrollo progresivo, sobre el cual ya se ha pronunciado el Comité de Derechos Económicos, Sociales y Culturales de las Naciones Unidas, se debe medir, en el criterio de este Tribunal, en función de la creciente cobertura de los derechos económicos, sociales y culturales en general, y del derecho a la seguridad social y a la pensión en particular, sobre el conjunto de la población, teniendo presentes los imperativos de la equidad social, y no en función de las circunstancias de un muy limitado grupo de pensionistas no necesariamente representativos de la situación general prevaleciente". ${ }^{45}$

El principio de progresividad no afecta la naturaleza jurídica de las obligaciones consignadas en las respectivas convenciones, ni niega la existencia de obligaciones inmediatas. Dicho principio sólo indica la existencia de una cierta flexibilidad que refleja las diversas realidades de los Estados Parte y las dificultades concretas de cada Estado en el aseguramiento inmediato de la plena efectividad de los derechos económicos, sociales y culturales. Asimismo, dichas frases deben interpretarse a la luz del objeto y fin de los respectivos tratados que es otorgar plena efectividad a los derechos respectivos. Asimismo hay obligaciones inmediatas que disponen los pactos y convenciones en materia de derechos económicos, sociales y culturales que no tienen un carácter de disposición de recursos financieros sino que buscan asegurar el respeto de los derechos en el nivel ya alcanzado, como asimismo, asegurar los contenidos esenciales de tales derechos, dar prioridad a los derechos en la distribución de los recursos, mejorar continuamente el goce y ejercicio de los derechos, adoptar medidas hasta el máximo de los recursos disponibles, la prohibición de medidas regresivas.

44 Comisión Interamericana de Derechos Humanos. Informe sobre la situación de los derechos humanos en el Ecuador. OEA/Ser. L/V/II.96, Doc. 10 rev. I, 24 de abril de 1997, p. 25. Segundo informe sobre los derechos humanos en el Perú, OEA/ Ser. L/V/II. 106 de junio 2000, Cap. VI., párrafo 6.

45 Corte Interamericana. Caso "Cinco Pensionistas" Vs. Perú. Sentencia de 28 de febrero de 2003. Serie C No. 98, párrafo 147. 
El principio de no regresividad se deriva del principio de progresividad, de no discriminación y del contenido esencial de los derechos económicos y sociales asegurados constitucionalmente, lo que implica un contenido indisponible de los derechos tanto individuales como económicos, sociales y culturales. Ello exige a los operadores jurídicos un estricto escrutinio de razonabilidad y proporcionalidad, especialmente cuando situaciones de crisis económica y social disminuyen el ámbito de atributos que contiene el derecho ya sea en cantidad o calidad, o garantizan en menor medida los derechos fundamentales que lo que ya contemplaba el ordenamiento jurídico.

Dicho principio de no regresividad, constituye asimismo una obligación general de la Convención Americana sobre Derechos Humanos, que cubre todos los derechos, incluido el artículo 26 de dicha Convención. A dicha conclusión permiten llegar dos disposiciones de la misma Convención, como son los artículos 2 y 29.

El artículo $2^{\circ}$ determina que "si el ejercicio de los derechos y libertades mencionados en el artículo $1^{\circ}$ no estuviere ya garantizado por disposiciones legislativas o de otro carácter, los Estados Parte se comprometen a adoptar, con arreglo a sus procedimientos constitucionales y a las disposiciones de esta Convención, las medidas legislativas o de otro carácter necesarias para hacer efectivos tales derechos y libertades".

A su vez, el artículo 29, referentes a normas de interpretación, precisa:

"ninguna disposición de la presente Convención puede ser interpretada en el sentido de:

“a) permitir a alguno de los Estados, grupo o persona, suprimir el goce o ejercicio de los derechos y libertades reconocidos en la Convención o limitarlos en mayor medida que la prevista en ella.

“b) limitar el goce y ejercicio de cualquier derecho o libertad que pueda estar reconocido de acuerdo con las leyes de cualquiera de los Estados Parte o de acuerdo con otra Convención en que sea parte uno de dichos Estados”.

De acuerdo con tales disposiciones, existe una prohibición de medidas que busquen derogar o eliminar de la legislación las disposiciones que son necesarias para el ejercicio de los derechos, lo cual, implica, establecer el principio de no regresividad normativa en materia de derechos, cuando se afecten normas y disposiciones que sean necesarias para el ejercicio de los derechos. ${ }^{46}$

En la sentencia de la Corte Interamericana sobre Derechos Humanos sobre el "caso Cinco Pensionistas con Perú”, el tribunal puso de manifiesto, el vínculo entre el movi-

46 Ver CourTis, Christian. (2006). "La prohibición de regresividad en materia de derechos sociales: apuntes introductorias"; en Courtis, Christian. (Comp.). Ni un paso atrás. La prohibición de regresividad en materia de derechos sociales. (Buenos Aires, Editorial Del Puerto), pp. 3-52. La misma materia es tratada por OJEDA MARín, A. (1996). Estado social y crisis económica. (Madrid, Ed. Universidad Complutense), pp. 91 y ss. 
miento progresivo de los derechos sociales, entre ellos el derecho a la seguridad social, por una parte, y la proyección que éste tiene "sobre el conjunto de la población", además del elemento de "equidad social” que debe caracterizar a dicha progresividad, por otra parte.

Tales principios de progresividad y no regresividad se encuentran también en los Principios de Limburgo sobre la implementación del PIDESC. Naciones Unidas, Doc. E/ C 4/1987/17, principio 25; y en los Principios de Maastricht sobre Violaciones a los Derechos Económicos, Sociales y Culturales, principio 9; en la Observación General $\mathrm{N}^{\circ} 3$ del Comité de Derechos Económicos, Sociales y Culturales de Naciones Unidas, Doc. E/1991/23; en el artículo 26 de la Convención Americana sobre Derechos Humanos y en el artículo $1^{\circ}$ del Protocolo Adicional a la Convención Americana sobre Derechos Humanos en materia de Derechos Económicos, Sociales y Culturales.

Como lo ha señalado el Comité de Derechos Económicos, Sociales y Culturales de Naciones Unidas, en su Observación General 3, párrafo 9 ${ }^{\circ}$, precisó:

"Además, todas las medidas de carácter deliberadamente retroactivo en este aspecto requerirán la consideración más cuidadosa y deberán justificarse plenamente por referencia a la totalidad de los derechos previstos en el Pacto y en el contexto del aprovechamiento pleno del máximo de recursos de que se disponga”.

A su vez, en las medidas a propósito del derecho a la salud, sobre el mismo punto de la no regresividad, el Comité dispuso:

“(...) si se adoptan cualesquiera medidas deliberadamente regresivas, corresponde al Estado Parte demostrar que se han aplicado tras el examen más exhaustivo de todas las alternativas posibles y que esas medidas están debidamente justificadas por referencia a la totalidad de los derechos enunciados en el Pacto en relación con la plena utilización de los recursos máximos disponibles del Estado Parte". ${ }^{47}$

A su vez, la obligación de no regresividad establece para el Estado la prohibición de empeorar el nivel de goce y ejercicio de un derecho económico, social o cultural desde la adopción del Pacto de Derechos Económicos, Sociales y Culturales de Naciones Unidas, como asimismo respecto de cada mejora progresiva en el goce y ejercicio de tales derechos. Tal como el Tratado exige la progresividad de los derechos, ello implica como exigencia lógica y mínima la no regresividad en el goce y ejercicio de tales derechos, vale decir, la no adopción que vaya a contracorriente de las obligaciones impuestas por el Pacto.

La no regresividad impone al Estado un deber negativo que exige a este y a sus autoridades y agentes, abstenerse de llevar a cabo políticas, prácticas, medidas legislativas o administrativas que vulneren los derechos de una persona o de un grupo de

47 Observación General 14 (el derecho al disfrute del más alto nivel posible de salud). Párrafo 32. 
personas que afecte el goce y ejercicio ya alcanzado en materia de derechos económicos, sociales y culturales.

Tal obligación de no regresividad en la medida que implica una actuación de abstención de afectación del derecho ha sido considerada como una obligación de respeto del derecho por parte del Estado respectivo, sus agentes y órganos. Esta obligación en la medida que no requiere ningún tipo de acción ni de prestación por parte del Estado constituye una materia de fácil revisión por los tribunales de justicia y por los tribunales constitucionales, como asimismo, por las instancias internacionales de protección y garantía de derechos humanos. ${ }^{48}$

El principio de no regresividad tiene un ámbito que no puede nunca ser traspasado y que constituye un límite absoluto a la regresividad que es el aseguramiento del contenido mínimo de cada derecho sin el cual el derecho se desnaturaliza, lo que indica que la regresividad cuando se encuentra justificada jamás puede afectar el contenido esencial o mínimo del derecho social asegurado, independientemente de los recursos económicos disponibles.

En el caso de adopción de medidas regresivas, la Observación General 3 del Comité de Derechos Económicos, Sociales y Culturales de Naciones Unidas, ha establecido que:

"Aún en tiempo de limitaciones graves de recursos, causadas sea por el proceso de ajuste, de recesión económica o por otros factores, se puede y se debe en realidad proteger a los miembros vulnerables de la sociedad mediante programas de relativo bajo costo". ${ }^{49}$

A su vez, la Observación General 4 del mismo Comité ha precisado que:

"Los Estados Parte deben otorgar la debida prioridad a los grupos sociales que viven en condiciones desfavorables concediéndoles una atención especial. Las políticas y la legislación, en consecuencia, no deben ser destinadas a beneficiar a los grupos sociales ya aventajados a expensas de los demás". ${ }^{0}$

Lo que nos señala que las medidas regresivas en materia de grupos vulnerables deben ser adoptadas solo en circunstancias muy extraordinarias, ya que el Estado debe proteger especialmente en tiempos de crisis a dichos grupos vulnerables, como exige el PIDESC, debiendo ser ellas sometidas a un escrutinio estrictísimo. Las medidas regresivas en materia de derechos sociales sólo se justifican si el Estado acredita que las restricciones han sido establecidas considerando todos los derechos que el

48 Rossı, Julieta. (2006). "La obligación de no regresividad en la jurisprudencia del Comité de Derechos Económicos, Sociales y Culturales”, en Courtis, Christian. (Comp.). Ni un paso atrás. La prohibición de regresividad en materia de derechos sociales. (Buenos Aires, Editorial Del Puerto), pp. 86 y 87.

49 Comité de Derechos Económicos, Sociales y Culturales de Naciones Unidas. Observación General 3, párrafo 12 .

50 Comité de Derechos Económicos, Sociales y Culturales de Naciones Unidas. Observación General 4, párrafo 11. 
PIDESC asegura y en un contexto de máxima utilización de los recursos disponibles, como lo determina la Observación General $N^{\circ} 3$ del Comité de Derechos Económicos, Sociales y Culturales de Naciones Unidas, en su párrafo 9.

En este sentido se han pronunciado también diversas jurisdicciones constitucionales, al respecto cabe mencionar la posición de la Corte Constitucional alemana, la cual ha otorgado protección a grupos de personas especiales por su vulnerabilidad, entre las cuales se cuentan las víctimas de la guerra y los perseguidos políticos, ${ }^{51}$ personas por nacer, ${ }^{52}$ personas con discapacidad ${ }^{53}$ personas vulnerables por carencia de recursos (ancianos, huérfanos). ${ }^{54}$

Asimismo, la Corte Constitucional alemana en un caso que debió resolver, luego de la reunificación alemana, respecto de la terminación de contratos laborales en servicios públicos en los nuevos estados alemanes, reconociendo el amplio poder de configuración legislativa del parlamento dictaminó sobre la proporcionalidad de las medidas y los límites que de ellas se derivaban para la protección de las personas de tercera edad, personas con discapacidad, mujeres embarazadas y de grupos especiales de trabajadores. ${ }^{55}$

El Tribunal Constitucional de Portugal, en su acuerdo 39/84, declaró inconstitucional una ley que derogaba buena parte del Servicio Nacional de Salud. Asimismo, declaró inconstitucional, la exclusión por medio de una ley de las personas de 18 a 25 años, del beneficio de rendimiento mínimo de inserción. Dicha decisión se fundamentó en la imposibilidad de retroceder en los avances sociales alcanzados por una determinada sociedad.

El Supremo Tribunal Federal de Brasil, en materia de salario de maternidad, decidió la imposibilidad de retroceso social, después de haber alcanzado cierto nivel de desarrollo. Flavio Pansieri explicita que la decisión se fundó en los objetivos estatales de desarrollo social y en la imposibilidad de aumentar las desigualdades por acción estatal o privada, sea por acción o por omisión. ${ }^{56}$

A su vez, la Sala Constitucional de la Corte Suprema de Costa Rica, en sentencia del $1^{\circ}$ de julio de 2009 , determinó que:

"De conformidad con lo anterior, se arriba a la conclusión que el proyecto de ley consultado es inconstitucional por suponer una medida regresiva en la plena efectividad de los derechos fundamentales al salario y a la seguridad social, pues, pretende excluir la remuneración que reciben los trabajadores de restaurantes,

51 Sentencia de la Corte Constitucional alemana, BverfGE 27, 253; 41, 126; 53, 164.

52 Sentencia de la Corte Constitucional alemana, BverfGE 75, 348.

53 Sentencia de la Corte Constitucional alemana, BverfGE 40, 121.

54 Sentencia de la Corte Constitucional alemana, BverfGE 56, 139.

55 Sentencia de la Corte Constitucional alemana, BverfGE 84, 133; 85, 360 (375).

56 PANSIERI, Flavio. (2006). "Condicionantes a sindicabilidade dos Direitos Sociais", em Revista da Academia Brasileira de Direito Constitucional, Volumen 10 A, Editora Jurua, Curitiva, p. 334. 
bares y establecimientos análogos, del rubro total que se contabiliza para las cargas sociales, disminuyendo, en consecuencia, su contribución, precisamente, al régimen administrado por la Caja Costarricense de Seguro Social para satisfacer prestaciones esenciales y engrosar su pensión por invalidez y vejez. El criterio de este tribunal, en virtud de las obligaciones contraídas por el Estado costarricense en aras de reconocer y garantizar la progresiva tutela de los derechos fundamentales económicos y sociales, no resulta conforme con el Derecho de la Constitución dictar medidas que supongan un retroceso en la tutela y efectividad de un derecho social, máxime, cuando este ha sido potenciado por la jurisprudencia del máximo Tribunal de Casación Laboral. En consecuencia, respecto a este extremo de la consulta, considera esta Sala que sí existe un vicio de inconstitucionalidad por el fondo". ${ }^{57}$

La prohibición de regresión es una prohibición prima facie, corresponde al Estado, una vez que se ha acreditado que la normativa es regresiva en el ámbito de un derecho, probar que han sido introducidas dichas medidas regresivas tras la consideración de todas las medidas posibles y encontrarse justificada teniendo en cuenta la totalidad de los derechos previsto en el Pacto en el contexto de la plena utilización del máximo de los recursos de que dispone el Estado y sin afectar el contenido esencial del derecho concernido, lo que está sujeto a un escrutinio estricto tanto del órgano de control jurisdiccional nacional, como asimismo por el órgano de control internacional.

Frente a la demostración de la existencia de una medida regresiva existe una presunción en contra de su validez, por lo cual, se invierte el peso de la carga de la prueba, debiendo demostrar el Estado que ella se encuentra justificada. Para ello debe acreditar:

a) Que el objetivo que se encuentra detrás de la medida regresiva es la preservación de la totalidad de los derechos previstos en el Pacto Internacional de Derechos Económicos, Sociales y Culturales, demostrando que la medida adoptada permite progresar en el ámbito de la generalidad de los derechos protegidos por el tratado.

b) Que el Estado ha considerado en forma exhaustiva todas las alternativas posibles previamente a la adopción de la medida restrictiva concreta de un derecho específico.', sin perjuicio de que la debe ser la menos lesiva del derecho en juego y ella es estrictamente necesaria, además de no afectar el contenido esencial o mínimo protegido del derecho.

c) Que la medida regresiva debió adoptarse aun cuando se hizo uso del máximo de recursos disponibles por el Estado y la sociedad, que implica no solo recursos financieros, sino también recursos naturales, humanos y tecnológicos.

57 Sentencia de la Sala Constitucional de la Corte Suprema de Costa Rica, de fecha $1^{\circ}$ de julio de 2009 , Exp: 09-007505-0007-CO; Res: 2009-10553. 
En el ámbito judicial, puede señalarse como ejemplo jurisprudencial del respeto de principio de no regresividad, la sentencia de la Cámara de Apelaciones en lo Contencioso Administrativo y Tributario de la Ciudad Autónoma de Buenos Aires:

“(...) La obligación de no regresividad constituye una limitación constitucional a la reglamentación de los derechos sociales, que veda en consecuencia a las autoridades públicas la posibilidad de adoptar medidas que reduzcan el nivel de los derechos sociales de que goza la población, más aún si se encuentra en situaciones de extrema precariedad y exclusión social. El Comité de Derechos Económicos, Sociales y Culturales (Observación General 4). En igual sentido se ha pronunciado la Comisión Interamericana de Derechos Humanos, al sostener que las condiciones de vigencia y acceso a los derechos sociales no pueden reducirse con el transcurso del tiempo, porque ello configura una violación del artículo 26 de la Convención Americana. En consecuencia, una vez garantizado el derecho a través de los diversos programas implementados a tal efecto, no podría luego la ciudad denegarlo por las supuestas inconductas en las que habría incurrido el demandante". ${ }^{58}$

En el contexto europeo puede ser mencionada una sentencia del Tribunal Constitucional de Portugal, la cual se pronuncia frente a una norma legislativa que dejando a salvo los derechos adquiridos reemplazaba el ingreso mínimo garantizado legislativamente desde los 18 años por una legislación que establecía un beneficio de un ingreso mínimo de inserción que excluía a las personas entre 18 y 25 años de edad. El Tribunal Constitucional emite una sentencia en que reconoce la exclusión y la regresividad de la norma legislativa declarándola inconstitucional basando su sentencia en el principio de no regresividad de los derechos sociales, que es aplicable no sólo frente a normas que derogan beneficios sociales, sino también cuando hay una afectación legislativa al contenido del derecho social fundamental ya concretado por el legislador. ${ }^{59} \mathrm{El}$ Tribunal Constitucional entendió que la legislación derogada que aseguraba un ingreso mínimo garantizado frente a la nueva legislación que introducía un ingreso social de inserción, excluye del beneficio a las personas entre 18 y 25 años, excluyó a ese segmento de la población del derecho a la seguridad social, violando el contenido mínimo de ese derecho que afecta la existencia digna, el cual debe ser asegurado en todos los casos, lo que constituye parte además del contenido esencial del derecho.

Constituye asimismo parte del sistema de pautas o principios de interpretación, la utilización del principio de razonabilidad y proporcionalidad como criterio de evaluación y ponderación de las regulaciones y restricciones de los derechos sociales fundamentales.

58 Sala I, Caso "Morón, Jorge Luis c/GIBA s/Amparo (art. 14 CCBA”, 8/10/2003, cons IV.2. Citado por CourTIS, Christian. (2006). "La prohibición de regresividad en materia de derechos sociales: apuntes introductorias"; en Courtis, Christian. (Comp.). Ni un paso atrás. La prohibición de regresividad en materia de derechos sociales. p. 23.

59 Sentencia del Tribunal Constitucional de Portugal, $N^{\circ}$ 509/2002, del 19 de diciembre de 2002. 
El principio de razonabilidad se encuentra tanto en los tratados de derechos humanos $^{60}$ como asimismo, en la jurisprudencia de los tribunales y cortes nacionales que ejercen control de constitucionalidad, lo que requiere un control de racionalidad y debido proceso sustantivo, que implica el que el derecho no sea afectado en su sustancia, el análisis que el medio legislativo sea acorde con el fin constitucionalmente perseguido, el análisis de que la medida legislativa sea la que menos afecte el derecho restringido o limitado, entre otros aspectos, por lo que el legislador o el órgano administrativo, en su caso, tienen prohibido la utilización de medidas irrazonables o arbitrarias.

Respecto del principio de proporcionalidad la Corte Interamericana lo ha aplicado a la restricción de los derechos, a manera ejemplar señalamos el considerando del siguiente fallo:

"La necesidad de las restricciones legalmente contempladas dependerá de que estén orientadas a satisfacer un interés público imperativo, siendo insuficiente que se demuestre, por ejemplo, que la ley cumple un propósito útil u oportuno. La proporcionalidad radica en que la restricción debe ajustarse estrechamente al logro de un legítimo objetivo, interfiriendo en la menor medida posible en el efectivo ejercicio del derecho restringido. Finalmente, para que sean compatibles con la Convención las restricciones deben justificarse según objetivos colectivos que, por su importancia, preponderen claramente sobre la necesidad del pleno goce del derecho restringido". ${ }^{61}$

Los principios de probidad y transparencia exigen al legislador y a la administración informar oportuna y adecuadamente de la adopción de medidas, decisiones o normas jurídicas con el objeto de cumplir las exigencias y obligaciones derivadas de los derechos económicos, sociales y culturales, eliminando la opacidad y discrecionalidad con que muchas veces opera el sistema de prestaciones sociales con sistemas clientelistas.

Considerar la constitucionalización del principio de seguimiento de los tribunales nacionales de los principios y parámetros interpretativos de las jurisdicciones supranacionales o internacionales a que el Estado ha reconocido jurisdicción en materia de derechos humanos, lo que contribuye a la generación de un derecho constitucional supranacional de carácter internacional y regional.

9.2.1.3. Las garantías jurisdiccionales. Las garantías jurisdiccionales son aquellas que buscan asegurar que un tercero imparcial, independiente de los órganos de gobierno y legislativo, como asimismo de los privados interesados o concernidos, obligados por los derechos sociales, pueda recibir los requerimientos, demandas o denuncias por incumplimiento de los deberes respecto de los derechos sociales asegu-

60 Ver PIDCP, Arts. $5^{\circ} .1 ; 12^{\circ} .3 ; 18^{\circ} .3 ; 19^{\circ} .3 ; 21^{\circ} ; 22^{\circ} .3$ y $25^{\circ}$. Convención Americana sobre Derechos Humanos, arts. $30^{\circ}$ y $32^{\circ}$.2. PIDESC, art. $4^{\circ}$. Protocolo de San Salvador, art. $5^{\circ}$.

61 Corte Interamericana de Derechos Humanos. Caso Comunidad Indígena Yakse Axa c. Paraguay. Sentencia de 17 de junio de 2005, párrafo 145. 
rados, determine a través de sus resoluciones su cumplimiento y establezca, cuando corresponda las reparaciones y sanciones respectivas. Ellos son normalmente los tribunales ordinarios o los tribunales administrativos, sin perjuicio, de la intervención en su caso de la jurisdicción constitucional.

Las garantías jurisdiccionales posibilitan a las personas afectadas en sus derechos a presentar ante los tribunales competentes sus denuncias, quejas o demandas ante los actos u omisiones antijurídicos que vulneran sus derechos.

La obligación de aseguramiento y protección de los derechos establecida por la Constitución en sus artículos $5^{\circ}$, inciso $2^{\circ}$, artículo $19^{\circ}$ y las garantías jurisdiccionales previstas en los artículos $20^{\circ}, 21^{\circ}$ y $93^{\circ}$ de la Carta Fundamental, se ve fortalecida por el artículo 25 de la Convención Americana de Derechos Humanos. Pacto de San José de Costa Rica, el cual prescribe:

“1. Toda persona tiene derecho a un recurso sencillo y rápido o a cualquier otro recurso efectivo ante los jueces o tribunales competentes, que la ampare contra actos que violen sus derechos fundamentales reconocidos por la Constitución, la ley o la presente Convención, aún cuando tal decisión sea cometida por personas que actúan en ejercicio de sus funciones oficiales.

2. "Los Estado Partes se comprometen.

a) A garantizar que la autoridad competente provista por el sistema legal del Estado decidirá sobre los derechos de toda persona que interponga tal recurso.

b) A desarrollar las posibilidades de recurso judicial.

c) A garantizar el cumplimiento, por las autoridades competentes, de toda decisión en que se haya estimado procedente el recurso".

Esta obligación del Estado debe concretarse a través de medios judiciales de derecho interno. Sólo cuando estos no existen o no son idóneos o efectivos, o ellos se hayan agotado, es posible recurrir a los mecanismos internacionales de protección. Así estos últimos son mecanismos subsidiarios y complementarios del derecho interno.

En el plano internacional tenemos el amparo interamericano de derechos previsto tanto para el caso de los derechos civiles y políticos, como para los derechos económicos, sociales y culturales, estos últimos de acuerdo con el protocolo de San Salvador que asegura y garantiza estos últimos derechos, protocolo que el Estado chileno aún no ha ratificado, siendo uno de los pocos países latinoamericanos que no lo ha hecho.

En el plano de la protección de los derechos a través de acciones de amparo, tutela o protección, es conveniente tener presente la necesidad de la defensa con medios eficaces de los derechos colectivos o difusos, que buscan tutelar a las personas en el seno de situaciones concretas de la sociedad, que requieren complementar la acción tutelar individual o del Estado por mecanismos de intervención social y colectiva. En este plano deben institucionalizarse las acciones de interés público (class action), que 
superan los límites individualistas de los mecanismos tradicionales de protección jurisdiccional de los derechos, posibilitando demandas de efectos colectivos, impulsadas por los grupos de personas afectadas como por asociaciones cívicas interesadas en su representación.

No puede dejar de mencionarse como una garantía jurisdiccional efectiva las acciones de inconstitucionalidad por omisión consideradas en diversos ordenamientos jurídicos, como por ejemplo, en Portugal (art. 283), Brasil (art. $103 \mathrm{~N}^{\circ} 2$ ), Costa Rica, algunas provincias argentinas. Esta inconstitucionalidad se verifica cuando el legislador o la administración no desarrollan la actividad ordenada por la Carta Fundamental para hacer plenamente efectivos los derechos contenidos en ella.

Los remedios procesales complementarios son aquellos que no han sido generados para proteger los derechos fundamentales, se utilizan para sancionar la violación de ellos, cuando ésta se ha consumado. Ejemplo de ellos es la responsabilidad extracontractual del Estado y de sus agentes por falta de servicio.

Los remedios procesales indirectos son aquellos configurados para la protección de los derechos que tienen un carácter ordinario (procesos civiles, penales, laborales, administrativos, etc.).

Asimismo, como ya lo expresamos en el párrafo de las garantías internacionales, en caso de no aseguramiento adecuado por las instancias nacionales de los derechos fundamentales, quedan abiertas las instancias internacionales del sistema interamericano (Comisión y Corte Interamericana de Derechos Humanos) y del sistema de protección de Naciones Unidas, el Comité de Derechos Económicos, Sociales y Culturales de Naciones Unidas.

Los tribunales tienen en nuestro ordenamiento jurídico, en cuanto órganos estatales, de acuerdo al artículo $5^{\circ}$, inciso $2^{\circ}$ de la Constitución de respetar y promover los derechos esenciales asegurados por la Constitución y los tratados internacionales sobre la materia. Para ello deben considerar tanto las fuentes formales de los derechos en el plano interno como las fuentes internacionales, las cuales determinan el carácter de aplicación directa de los derechos en su contenido esencial y básico siempre, además de los atributos configurados legalmente, cuando son requeridos por las personas afectadas, dentro del ámbito de sus competencias.

\section{LA JUSTICIABILIDAD DE LOS DERECHOS ECONÓMICOS, SOCIALES Y CULTURALES}

El Comité de Derechos Económicos, Sociales y Culturales de Naciones Unidas, en sus Observaciones Generales sobre Implementación del Pacto Internacional de Derechos Económicos, Sociales y Culturales, ha determinado que los Estados Parte tienen la obligación de procurar la plena eficacia de tales derechos "por todos los medios 
apropiados", que establece el artículo 2.1 del Pacto en consideración. Es el Estado Parte sobre el que recae el deber de demostrar que frente a una determinada situación, el mecanismo judicial no es el apropiado o no es necesario. Asimismo el Comité ha advertido que los "demás 'medios' utilizados puedan resultar ineficaces si no se refuerzan o complementan con recursos judiciales". ${ }^{62}$

Las concepciones que niegan la justiciabilidad de los derechos económicos, sociales y culturales no son compatibles con las obligaciones de los Estados Partes derivadas del Pacto Internacional de Derechos Económicos, Sociales y Culturales. Sobre la materia el Comité de Derechos Económicos, Sociales y Culturales de Naciones Unidas ha sostenido:

"Aunque sea necesario tener en cuenta el planteamiento general de cada uno de los sistemas jurídicos, no hay ningún derecho reconocido en el Pacto que no se pueda considerar que posee en la gran mayoría de los sistemas algunas dimensiones significativas, por lo menos de justiciabilidad. A veces se ha sugerido que las cuestiones que suponen una asignación de recursos deben remitirse a las autoridades políticas y no a los tribunales. Aunque haya que respetar las competencias respectivas de los diversos poderes, es conveniente reconocer que los tribunales ya intervienen generalmente en una gama considerable de cuestiones que tienen consecuencias importantes para los recursos disponibles. La adopción de una clasificación rígida de los derechos económicos, sociales y culturales que los sitúe por definición, fuera del ámbito de los tribunales sería, por lo tanto, arbitraria e incompatible con el principio de que los dos grupos de derechos son indivisibles e interdependientes. También se reduciría drásticamente la capacidad de los tribunales para proteger los derechos de los grupos más vulnerables y desfavorecidos de la sociedad". ${ }^{63}$

En tal sentido, el Comité de Derechos Económicos, Sociales y Culturales, ya había determinado:

"Entre las medidas que cabría considerar apropiadas, además de las legislativas, está la de ofrecer recursos judiciales en lo que respecta a derechos que, de acuerdo con el sistema jurídico nacional, puedan considerarse justiciables. El comité observa, por ejemplo, que el disfrute de los derechos reconocidos, sin discriminación, se fomentará a menudo de manera apropiada, en parte mediante la provisión recursos judiciales y otros recursos efectivos. De hecho, los Estados Parte que son asimismo parte en el Pacto Internacional de Derechos Civiles y Políticos ya están obligados (en virtud de los artículos 2 [párrafo 1 y 3], 3 y 26 de este Pacto) a garantizar que toda persona cuyos derechos o libertades (inclusive el derecho a la igualdad y a la no discriminación) reconocidos en el presente Pacto hayan sido violados 'podrá interponer un recurso efectivo' (apartado a del párrafo 3 del artículo $2^{\circ}$ ). Además, existen en el Pacto Internacional de Derechos

62 Observación General № 9, E/C. 12/1998/24, 3 de diciembre de 1998.

63 Observación General № 9, E/C. 12/1998/24, 3 de diciembre de 1998. 
Económicos, Sociales y Culturales varias otras disposiciones, entre ellas los artículos 3, 7 (inciso i) del apartado a, 8, 10 (párrafo 3), 13 (apartado a del párrafo 2 y párrafos 3 y 4) y 15 (párrafo 3), que cabría considerar de aplicación inmediata por parte de los órganos judiciales y de otra índole en numerosos sistemas legales nacionales. Parecería difícilmente sostenible sugerir que las disposiciones indicadas son intrínsecamente no auto ejecutables". ${ }^{64}$

El Comité de Derechos Económicos, Sociales y Culturales de Naciones Unidas, en su Observación General $N^{\circ}$ 9, ha precisado:

"[...] A este respecto, es importante distinguir entre justiciabilidad (que se refiere a las cuestiones que pueden o deben resolver los tribunales) y las normas de aplicación inmediata (que permiten su aplicación por los tribunales sin más disquisiciones). Aunque sea necesario tener en cuenta el planteamiento general de cada uno de los sistemas jurídicos, no hay ningún derecho reconocido en el Pacto que no se pueda considerar que posee en la gran mayoría de los sistemas algunas dimensiones significativas, por lo menos de justiciabilidad. A veces se ha sugerido que las cuestiones que suponen una asignación de recursos deben remitirse a las autoridades políticas y no a los tribunales. Aunque haya que respetar las competencias respectivas de los diversos poderes, es conveniente reconocer que los tribunales ya intervienen generalmente en una gama considerable de cuestiones que tienen consecuencias importantes para los recursos disponibles. La adopción de una clasificación rígida de los derechos económicos, sociales y culturales que los sitúe, por definición, fuera de los ámbitos de los tribunales sería, por lo tanto, arbitraria e incompatible con el principio de que los grupos de derechos son indivisibles e interdependientes. También se reduciría drásticamente la capacidad de los tribunales para proteger los derechos de los grupos más vulnerables y desfavorecidos de la sociedad". ${ }^{65}$

Los derechos sociales fundamentales se basan en la interpretación de una o diversas normas o partes de normas constitucionales, como asimismo, fuentes del derecho internacional que contienen atributos de derechos fundamentales, debidamente incorporados al derecho interno, lo que exige una interpretación integrada de todo el texto constitucional y sus fuentes interna e internacional. Los derechos sociales fundamentales exigen una interpretación sistemática y finalista del texto constitucional, además de una interpretación dinámica o actualizada en algunos casos.

Ello implica que los operadores jurídicos (especialmente, de los jueces ordinarios y constitucionales) de tomar los derechos en serio, despojándose de prejuicios y preconceptos, en una perspectiva de asegurar, respetar, garantizar y promover efectivamente los derechos a través de reglas de interpretación y argumentación jurídica,

64 Observación General 3, “La índole de las obligaciones de los Estados Parte”, 1990, párrafo 5.

65 Comité de Derechos Económicos, Sociales y Culturales de Naciones Unidas, en su Observación General $\mathrm{N}^{\circ}$ 9. "La aplicación interna del Pacto". 1998. Párrafo 10. 
dando razones válidas y suficientes para respaldar su existencia y su ejercicio por parte de las personas.

Así por ejemplo, la Corte Constitucional alemana ha establecido la existencia de un derecho fundamental a un mínimo existencial (Existenzminimum) que no se encuentra explicitado positivamente en la Constitución. El derecho a un mínimo vital se extrae por la jurisprudencia administrativa y constitucional del artículo 1 , párrafo $1^{\circ}$, junto con el artículo $2^{\circ}, 3^{\circ}$ inciso 1 , en conexión con el artículo 20 , inciso 1 de la Ley Fundamental, a través de una interpretación sistemática y finalista. La argumentación parte de la afirmación de la dignidad de la persona humana asegurada por el artículo $1^{\circ}$ de la Ley Fundamental y el derecho al libre desarrollo de la personalidad del artículo $2^{\circ}$ inciso 1 , o en el derecho a la vida y la inalienabilidad corporal del artículo $2^{\circ}$ inciso 1 el principio de igualdad del artículo $3^{\circ}$ inciso 1 , en conexión con el principio de Estado social de Derecho del artículo 20 de la Ley Fundamental. Así, cuando a una persona no se le reconoce su derecho a un mínimo existencial, se vulnera al menos el derecho fundamental a la vida y a la inalienabilidad corporal.

Los derechos sociales fundamentales se construyen interpretativamente considerando diversos enunciados normativos o partes de ellos. Así cuando la falta de reconocimiento de una posición jurídica ocasiona un daño a una persona sin justificación, dicha posición jurídica debe ser reconocida. Por lo tanto un derecho social es exigible al Estado, sus órganos o instituciones, cuando la omisión estatal dañe inminentemente a dicho ser humano sin que exista una justificación para ello, en cuyo caso de no asegurarse el derecho social se vulneraría el texto constitucional.

Nuestra Constitución, en su artículo $1^{\circ}$, inciso 1 , asegura que "las personas nacen libres e iguales en dignidad y derechos”, asimismo, el inciso $5^{\circ}$, precisa el deber del Estado de "promover la integración armónica de todos los sectores de la Nación y asegurar el derecho de las personas a participar con igualdad de oportunidades en la vida nacional".

El derecho constitucional democrático contemporáneo presuponen la dignidad y la igualdad y libertad esenciales de las personas, además de asegurar la protección de ellas ante factores que atenten contra tales presupuestos, asegurando las circunstancias reales que posibiliten el ejercicio efectivo de la libertad y la igualdad de oportunidades, protegiendo a las personas frente a riesgos naturales o sociales a los que está expuesto como señala Alexy, de manera tal que todos puedan desarrollar al máximo posible sus potencialidades o su libertad, en su dimensión de exultación. Así se desarrolla la función subsidiaria del Estado frente a los derechos sociales fundamentales cuando el individuo no puede obtenerlos mediante su libertad en su dimensión de autonomía y las condiciones materiales ameriten una activación de las obligaciones positivas del Estado, producto de la situación particular frente a los recursos y los bienes primarios o las capacidades actuales de cada persona.

El hecho que el Estado sea subsidiario u obligado secundario en esta materia, se debe a que el ordenamiento constitucional otorga una primacía a la persona, desarro- 
llando una concepción personalista o instrumental del Estado, el cual según determina el texto constitucional, en su artículo $1^{\circ}$, inciso 3 , "está al servicio de la persona humana y su finalidad es promover el bien común".

Así, siguiendo a Arango, estamos frente a un derecho social fundamental, prima facie, cuando una o muchas personas se encuentran en un estado de necesidad y el Estado dispone de la posibilidad efectiva de satisfacerla o reducirla, pero omite hacerlo, y tal omisión amenaza inminentemente con producir un daño a esa o esas personas, en cuyo caso, ellas tienen el derecho a la acción positiva fáctica del Estado. ${ }^{66}$ Razones que puedan oponerse justificadamente y que pueden prevalecer pueden impedir el reconocimiento final de dicho derecho social fundamental, lo que exige una argumentación jurídica convincente y razonable. De lo contrario el derecho prima facie se convierte en derecho exigible efectivamente.

La Corte Constitucional colombiana ha desarrollado una amplia jurisprudencia en este ámbito, a modo ejemplar señalamos la siguiente sentencia:

"La Constitución consagra diversos mecanismos tendiente a garantizar a las personas en situaciones de indigencia los servicios públicos básicos de salud (C.P. art. 49), seguridad social integral (C.P. arts. 46 y 48) y el subsidio alimentario (C.P. art. 46). En principio, el legislador es la autoridad pública llamada a determinar la forma y la cobertura de la prestación. En casos excepcionales, no obstante, puede haber lugar a la aplicación inmediata ( C.P. art. 85) de la protección especial a la persona, en particular cuando la marginalidad social y económica la coloca en circunstancias de debilidad manifiesta (C.P. art. 13).

(...) "Se justifica exigir a la persona que acuda a sus familiares más cercanos en búsqueda de asistencia o protección antes de hacerlo ante el Estado, salvo que exista un derecho legalmente reconocido a la persona y a cargo de éste, o peligren otros derechos constitucionales fundamentales que ameriten una intervención inmediata de las autoridades (C.P. art. 13) ..(...)”.

"La solidaridad y el apoyo a la persona que se encuentra en situación de indigencia y sufre quebrantos de salud corresponde prioritariamente a la familia. Los miembros de ésta, determinados por la ley, tienen la obligación jurídica y moral de auxiliar a sus descendientes o ascendientes próximos”.

"No obstante, si la familia se encuentra en imposibilidad material de apoyar uno de sus miembros, se pueden quedar éstos irremediablemente abandonados a su suerte. El Estado, en desarrollo de sus fines esenciales, está en el deber constitucional de proteger efectivamente los derechos de la persona, correspondiendo a la autoridad pública encontrar las alternativas jurídicas para garantizar su ejercicio y, al mismo tiempo, exigir el cumplimiento de las obligaciones sociales de los particulares (C.P. art. 2)".

"Cuando una persona demuestra la circunstancia de debilidad manifiesta en que se encuentra, debido a su condición económica, física o mental (C.P. art. 13), sin

66 Arango, Rodolfo. (2005). El concepto de derechos sociales fundamentales, p. 167. 
que ella misma o su familia puedan responder, excepcionalmente se genera para el Estado una obligación de proteger especialmente a la persona colocada en dicha situación".

"Los derechos a la salud (C.P. art. 49) a la seguridad social integral (C.P. art. 48), y a la protección y asistencia a la tercera edad (C.P. art. 46), en principio programáticos, pueden ser actualizados y generar un derecho público subjetivo de inmediata aplicación (C.P. arts. 13 y 85), si la persona interesada demuestra fehacientemente su condición de debilidad manifiesta y la imposibilidad material de su familia para darle asistencia, en particular cuando la completa ausencia de apoyo la priva de un derecho al mínimo vital".

"En tal evento, se opera una inversión en el orden de exigibilidad del principio de solidaridad social, que obliga al Estado a una prestación directa e inmediata a favor de la persona que se halla en la circunstancia de debilidad manifiesta, sin perjuicio del derecho en cabeza de la autoridad estatal, cuando sea el caso, al reintegro posterior de su costo por parte de beneficiario y de su familia.". ${ }^{67}$

En este caso hay razones válidas y suficientes para fundamentar la exigibilidad del derecho frente al Estado. El derecho a la prestación médica tiene una justificación mediante una interpretación y argumentación sistemática de la Constitución, frente a la cual la oposición de los principios de división de poderes y libre configuración del legislador de los derechos, como en los derechos de los demás, aparece débil, ya que la mantención de una situación de inactividad del Estado genera un daño irreparable a la integridad física y psíquica de la persona.

Precisar el carácter justiciable de los derechos económicos, sociales y culturales, no significa que a través de sentencias se cambiará la realidad económico social del país ni se solucionarán los problemas de redistribución de la riqueza y los ingresos, lo que es propio de las políticas públicas que deben desarrollar los respectivos gobiernos.

Sin embargo, la injustificada negativa a proporcionar una prestación vinculada a un derecho económico, social o cultural, como asimismo, la omisión de adopción de medidas de garantías de tales derechos constituyen formas de arbitrariedad de ejercicio del poder público o de negligencia funcionaria, las cuales deben ser rechazadas y superadas mediante todo el arsenal de instrumentos y acciones judiciales y administrativas disponibles.

Los jueces legítimamente deben intervenir cuando son requeridos, ya sea porque organismos estatales o instituciones privadas se nieguen arbitraria o ilegalmente a proporcionar las prestaciones debidas, o cuando el Estado a través de sus diversos órganos retrocedan injustificadamente en el ámbito de protección de los derechos sociales, vulnerando el principio de progresividad e irreversibilidad de los derechos humanos o fundamentales sin causas de fuerza mayor que lo justifiquen. Así la justicia

67 Sentencia de la Corte Constitucional de Colombia, ST-533 de 1992, fundamentos 1, 3 y 5. 
ordinaria y la jurisdicción constitucional tienen la misma obligación de asegurar y garantizar los derechos humanos en su conjunto con la misma fuerza, sean estos derechos civiles y políticos o económicos, sociales y culturales.

Como lo ha sostenido el Comité de Derechos Económicos, Sociales y Culturales en su Observación General $N^{\circ}$ 9:

"A veces se ha sugerido que las cuestiones que suponen una asignación de recursos deben remitirse a las autoridades políticas y no a los tribunales. Aunque haya que respetar las competencias respectivas de los diversos poderes, es conveniente reconocer que los tribunales ya intervienen generalmente en una gama considerable de cuestiones que tienen consecuencias importantes para los recursos disponibles. La adopción de una clasificación rígida de derechos económicos, sociales y culturales que los sitúe, por definición, fuera del ámbito de los tribunales sería, por tanto, arbitraria e incompatible con el principio de que los dos grupos de derechos son indivisibles e interdependientes. También se reduciría drásticamente la capacidad de los tribunales para proteger los derechos de los grupos más vulnerables y desfavorecidos de la sociedad” (Párrafo 10).

Por ello, la misma Observación General $\mathrm{N}^{\circ} 9$ comentada, en su párrafo 11 señala la importancia de informas a los jueces y tribunales de la naturaleza y consecuencias del Pacto Internacional de Derechos Económicos, Sociales y Culturales de Naciones Unidas, así como la importancia que tienen los recursos judiciales en su respeto y efectiva garantía.

La Comisión Interamericana de Derechos Humanos ha determinado que el derecho a la tutela judicial efectiva de los derechos contenidos en el artículo 25 de la Convención Americana sobre Derechos Humanos exige:

1) La obligación del Estado de crear un recurso sencillo y rápido, preferentemente de carácter judicial para la protección de los derechos, aun cuando otros recursos son admisibles en la medida que sean efectivos respecto de la tutela de los derechos contenidos en la Convención, la Constitución y las leyes.

2) La exigencia de que el recurso sea efectivo.

3) que la víctima de la violación del derecho pueda interponer efectivamente el recurso acción judicial.

4) la exigencia que el estado Parte asegure que la acción o recurso será efectivamente considerado por los tribunales.

5) que la acción o recurso pueda ser efectivamente dirigido contra órganos o autoridades públicas, como asimismo respecto de personas o sujetos privados.

6) La obligación estatal de desarrollar la acción o recurso judicial, y

7) La obligación del Estado y sus órganos y autoridades de cumplir lo resuelto en la decisión o resolución judicial dictada a partir de la acción o recurso. ${ }^{68}$

68 Comisión Interamericana de Derechos Humanos. El acceso a la justicia como garantía de los derechos económicos, sociales y culturales. Estudio de los estándares fijados por el sistema interamericano de derechos humanos. Washington DC, OEA Documentos oficiales 2007, OEA/Ser.L/V/II, párrafo 241. 
Como ha señalado el Comité de Derechos Económicos, Sociales y Culturales de Naciones Unidas, en su Observación General 9, párrafo 14:

"dentro de los límites del ejercicio adecuado de sus funciones de examen judicial, los tribunales deben tener en cuenta los derechos reconocidos en el pacto cuando sea necesario para garantizar que el comportamiento del Estado está en consonancia con las obligaciones emanantes del pacto. La omisión por parte de los tribunales de esta responsabilidad es incompatible con el principio de imperio del derecho, que siempre ha de suponerse que incluye el respeto a las decisiones internacionales en materia de derechos humanos".

Por otra parte, debe tenerse presente también la obligación del control de convencionalidad, tal como lo ha precisado la Corte Interamericana de Derechos humanos, que los tribunales nacionales deben realizar respecto de las normas jurídicas de derecho interno que no sean compatibles con las obligaciones convencionales o establezcan estándares de aseguramiento de derecho inferiores a los fijados por el derecho convencional y sus órganos de aplicación:

“123. La descrita obligación legislativa del artículo 2 de la Convención tiene también la finalidad de facilitar la función del Poder Judicial de tal forma que el aplicador de la ley tenga una opción clara de cómo resolver un caso particular. Sin embargo, cuando el Legislativo falla en su tarea de suprimir y/o no adoptar leyes contrarias a la Convención Americana, el Judicial permanece vinculado al deber de garantía establecido en el artículo 1.1 de la misma y, consecuentemente, debe abstenerse de aplicar cualquier normativa contraria a ella. El cumplimiento por parte de agentes o funcionarios del Estado de una ley violatoria de la Convención produce responsabilidad internacional del Estado, y es un principio básico del derecho de la responsabilidad internacional del Estado, recogido en el Derecho Internacional de los Derechos Humanos, en el sentido de que todo Estado es internacionalmente responsable por actos $u$ omisiones de cualesquiera de sus poderes u órganos en violación de los derechos internacionalmente consagrados, según el artículo 1.1 de la Convención Americana.

“124. La Corte es consciente que los jueces y tribunales internos están sujetos al imperio de la ley y, por ello, están obligados a aplicar las disposiciones vigentes en el ordenamiento jurídico. Pero cuando un Estado ha ratificado un tratado internacional como la Convención Americana, sus jueces, como parte del aparato del Estado, también están sometidos a ella, lo que les obliga a velar porque los efectos de las disposiciones de la Convención no se vean mermadas por la aplicación de leyes contrarias a su objeto y fin, y que desde un inicio carecen de efectos jurídicos. En otras palabras, el Poder Judicial debe ejercer una especie de "control de convencionalidad" entre las normas jurídicas internas que aplican en los casos concretos y la Convención Americana sobre Derechos Humanos. En esta tarea, el Poder Judicial debe tener en cuenta no solamente el tratado, sino también la interpretación que del mismo ha hecho la Corte Interamericana, intérprete última de la Convención Americana.

125. En esta misma línea de ideas, esta Corte ha establecido que "Is]egún el derecho internacional las obligaciones que éste impone deben ser cumplidas de 
buena fe y no puede invocarse para su incumplimiento el derecho interno". Esta regla ha sido codificada en el artículo 27 de la Convención de Viena sobre el Derecho de los Tratados de 1969". ${ }^{9}$

\section{CREACIÓN DE OTROS RECURSOS LEGALES, FUERA DE LOS JUDICIALES, PARA PROTEGER LOS DERECHOS SOCIALES}

El Comité de Derechos Económicos, Sociales y Culturales en su Observación General $\mathrm{N}^{\circ} 9$, reconoce a los recursos administrativos también como adecuados para la protección de los derechos sociales, en la medida de que "quienes viven bajo la jurisdicción de un Estado Parte tienen la expectativa legítima de que, sobre la base del principio de buena fe, todas las autoridades administrativas, al adoptar decisiones, tendrán en cuenta las disposiciones del Pacto". La Observación general $\mathrm{N}^{\circ} 9$ precisa que tales recursos administrativos deben ser accesibles, rápidos y eficaces, no onerosos, debiendo existir la posibilidad de plantear una apelación judicial contra todo proceso administrativo (párrafo 9).

\section{DETERMINACIÓN DEL CONTENIDO DE LOS DERECHOS ECONÓMICOS, SOCIALES Y CULTURALES O DERECHOS SOCIALES FUNDAMENTALES}

En este sentido el contenido mínimo de cada derecho deriva del respeto y promoción de la dignidad humana, como asimismo su contenido esencial que ampara todo el derecho delimitado constitucionalmente o por el bloque constitucional de derechos, según el Estado respectivo, ámbitos que están amparados por su justiciabilidad en cuanto tales derechos constituyen vinculaciones directas para todas las autoridades y órganos estatales y todas las personas. Dicha justiciabilidad se dará en casos en que exista una relación jurídica definida en que la lesión del derecho provenga de una modificación o desconocimiento de la esfera jurídica de una persona o de un grupo de ellas, de la eventual debilidad manifiesta de la misma persona, como también, en los casos en que faltando la relación jurídica preexistente, una persona o un grupo de ellas se encuentre ante exclusiones arbitrarias o injustificadas de acceso a prestaciones o servicios, como puede ser la negativa de acceso a un establecimiento público de enseñanza básica estatal, la negación de acceso a una prestación de salud básica por parte de servicios públicos en casos de peligro de muerte o de grave menoscabo de la integridad de la integridad física o psíquica en conexión con la salud de la persona.

El contenido mínimo de los derechos sociales fundamentales está relacionado con el respeto a la dignidad del ser humano y a la consideración de un mínimo vital que se concreta en cada uno y todos los derechos económicos, sociales y culturales en cuan-

69 Sentencia de la Corte Interamericana de Derechos Humanos, de 26 de septiembre de 2006. Serie C $\mathrm{N}^{\circ}$ 154, párrafos 123-125. 
to satisfacción de necesidades materiales básicas de las personas, constituyendo el aseguramiento de la existencia material del ser humano un presupuesto básico del Estado constitucional democrático contemporáneo. Ello implica tanto acciones positivas por parte del Estado como prohibiciones de retrocesos injustificados de acciones previamente configuradas en el ordenamiento constitucional y legal, dentro de un contexto fáctico y normativo determinado, que reconoce el derecho de configuración del legislador en cuanto órgano de representación democrática, sujeto al control de constitucionalidad ejercido por la jurisdicción constitucional respectiva.

Así en el ámbito del Pacto Internacional de Derechos Económicos, Sociales y Culturales, los Estados parte deben abstenerse de actuar si con ello afectan los derechos, asimismo deben prevenir su afectación en su interrelación con los particulares y deben adoptar medidas que propendan a su plena realización.

La realización progresiva de los derechos económicos, sociales y culturales que tienen los Estados ha sido desagregada por el Comité de Derechos Económicos, Sociales y Culturales de Naciones Unidas en varias obligaciones: la obligación de adoptar medidas inmediatas, las cuales incluyen la obligación de garantizar que los derechos se ejerzan sin discriminación, la obligación de garantizar niveles esenciales o básicos en todos los derechos, la obligación de proteger con carácter prioritario a los grupos vulnerables y la obligación de no regresividad e materia del nivel alcanzado de ejercicio y garantía en los derechos, como se estableció ya en la Observación General $N^{\circ} 3$ de dicho Comité.

En tal sentido, la Corte Constitucional de Colombia ha precisado que:

"El derecho fundamental al mínimo vital presenta una dimensión positiva y una negativa. La dimensión positiva de este derecho fundamental presupone que el Estado, y ocasionalmente los particulares, cuando se reúnen las condiciones de urgencia y otras señaladas en las leyes y en la jurisprudencia constitucional, están obligados a suministrar a la persona que se encuentra en una situación en la cual ella misma no se puede desempeñar autónomamente y que compromete las condiciones materiales de su existencia, las prestaciones necesarias e indispensables para sobrevivir dignamente y evitar su degradación o aniquilamiento como ser humano. Por su parte, respecto de la dimensión negativa, el derecho fundamental al mínimo vital se constituye en un límite o cota inferior que no puede ser traspasada por el Estado, en materia de disposición de los recursos materiales que la persona necesita para llevar una existencia digna. Es por ello que instituciones como la inembargabilidad de parte del salario, la prohibición de la confiscación, la indisponibilidad de los derechos laborales o el amparo de pobreza, entre otros, constituyen ejemplos concretos del mencionado límite inferior que excluye ciertos recursos materiales de la competencia dispositiva del Estado o de otros particulares". ${ }^{70}$

70 Sentencia de la Corte Constitucional de Colombia, C-776 de 2003. Puede verse en el mismo sentido, entre otras las siguientes sentencias: Sentencia C-251 de 1997; T-595 de 2002; T-680-2003. 
Los tribunales de diversos países latinoamericanos así lo han entendido, de lo cual daremos aquí algunos ejemplos.

La Corte Suprema de Venezuela, en su Sala Político Administrativa, desde 1998, según precisa Casal, "declaró con lugar recursos dirigidos a asegurar el suministro de medicamentos y de tratamiento medico a afectados por el VIH, siendo de singular relevancia la sentencia dictada el 15 de julio de 1999, porque declaró obligatorio tal suministro en beneficio no sólo de los accionantes, sino de todo venezolano o extranjero residente en el país que padezca de VIH/SIDA, acredite la necesidad de tratamiento y carezca de recursos necesarios para sufragarlo. Para garantizar el cumplimiento del fallo se ordenó al Ministro de Sanidad y Asistencia Social solicitar al Presidente de la República la rectificación de la respectiva partida presupuestaria o la tramitación de un crédito adicional al presupuesto para el resto del ejercicio fiscal, así como gestionar la inclusión de los recursos necesarios en futuros proyectos de ley de presupuesto. La Sala Constitucional del Tribunal Supremo de Justicia, creada por la Constitución de 1999, ha consolidado esta línea jurisprudencial, pero en relación con las personas inscritas en el Instituto Venezolano de los Seguros Sociales, sin que se exija en este caso la carencia de recursos económicos para cubrir los costos del tratamiento". ${ }^{71}$

En el mismo caso de Venezuela, respecto del derecho a la vivienda, la Sala Constitucional del Tribunal Supremo de Justicia, en sentencia $N^{\circ} 85$ de 2002, declaró ilícitas las condiciones en que la banca privada venía otorgando créditos hipotecarios por la falta de intervención del Banco Central de Venezuela en la fijación de límites a las tasas de interés y por el uso de créditos indexados en supuestos no autorizados por la ley. La resolución ordenó el recálculo de los créditos hipotecarios otorgados, con arreglo a una tasa máxima de interés que fijaría el Banco Central de Venezuela, imputándose los intereses indebidamente cobrados al capital adeudado por las personas afectadas.

En Argentina, en el caso Viceconte, Mariela c/ Ministerio de Salud y Acción Social, referente a la negligencia del Estado respecto de la elaboración o contratación de vacuna contra la Fiebre Hemorrágica Argentina, dado que un Laboratorio Norteamericano al cual se había encargado la vacuna Candid I , el cual había informado al Estado que no continuaría la producción de dicha vacuna por no ser rentable, tras lo cual el Estado argentino inició la tarea de su fabricación incurriendo el larga demora, que provocó la interposición de una acción de amparo resulto por la Cámara Nacional de Apelación en lo Contencioso Administrativo Federal, en su Sala IV, que, el 2 de julio de

71 CASAL, Jesús María. "La protección internacional y constitucional de los derechos sociales”. Casal, Jesús María. La protección internacional y constitucional de los derechos sociales. En Casal, Jesús María; Arismendi, Alfredo y Carrillo, Carlos Luis (coordinadores). Tendencias actuales del derecho constitucional. Homenaje a Jesús María Casal Montbrun. Tomo II. Ed. Universidad Central de Venezuela - Universidad Católica Andrés Bello, Caracas, Venezuela, 2007, p. 24. El autor cita las sentencias de la Corte Suprema de Venezuela, en su Sala Político Administrativa, de 20 de enero de 1998 y de 14 de agosto de 1998, como asimismo, sentencias de la Sala Constitucional del Tribunal Supremo de Justicia $\mathrm{N}^{\circ}$ 487/ 2001 de 6 de abril, reiterada en sentencia $N^{\circ} 881 / 2002$, de 8 de mayo. 
1998 determinó la procedencia de la acción y ordenó al Ministerio de Salud y Acción Social desarrollar la producción de la vacuna con estricto apego al cronograma que las autoridades habían determinado originalmente.

Asimismo, la Corte Suprema Argentina en el caso Campodónico, Ana c/Ministerio de Salud y Acción Social ordenó al Estado Argentino entregar regularmente un medicamento de alto costo a un niño que padecía de una grave enfermedad ósea. ${ }^{72}$ En este caso la Corte Suprema Argentina preciso que el derecho a la preservación de la salud tiene rango constitucional a partir de lo dispuesto en los tratados internacionales; que la autoridad pública tiene la obligación impostergable de garantizar tal derecho a través de acciones positivas; que los pactos internacionales protegen especialmente la salud y vida de los niños; que el Pacto Internacional de Derechos Económicos, Sociales y Culturales reconoce el derecho de todas las personas a disfrutar del más alto nivel posible de salud física y mental, así como el deber de los estados parte de procurar su satisfacción; que los estados partes se han obligado "hasta el máximo de los recursos" que dispongan para lograr progresivamente la plena efectividad de los derechos reconocidos en dicho tratado; que la Convención sobre Derechos del Niño incluye, además, la obligación de los estados de garantizar a los menores con impedimentos físi$\cos$ y/o mentales el acceso efectivo a los servicios sanitarios y a la rehabilitación, de esforzarse porque no sean privados de esos servicios y de lograr cabal realización del derecho a beneficiarse de la seguridad social, para lo cual se debe tener en cuenta la legislación nacional, los recursos y la situación de cada infante y de las personas responsables de su mantenimiento.

La Corte determina que “(...) el Estado Nacional ha asumido, pues, compromisos internacionales explícitos encaminados a promover y facilitar las prestaciones de salud que requiere la minoridad y no puede desligarse válidamente de esos deberes, so pretexto de la inactividad de otras entidades públicas o privadas, máxime cuando ellas participan de un mismo sistema sanitario y lo que se halla en juego es el interés superior del niño, que debe ser tutelado por sobre otras consideraciones por todos los departamentos gubernamentales" ${ }^{73}$

La Corte Constitucional Colombiana ha desarrollado un interesante enfoque de aplicación inmediata e imperativa de derechos prestacionales en conexión con derechos individuales, como salud y vida, dignidad humana y omisión de prestación de derecho de carácter económico social, todo ello mediante una adecuada ponderación en las circunstancias específicas del caso.

72 Sentencia de la Corte Suprema de Justicia de la Nación de 24 de octubre de 2000. Campodónico de Beviacqua, Ana Carina c/ Ministerio de Salud y Acción Social -Secretaría de Programas de Salud y Banco de Drogas Neoplásicas s/Recurso de Hecho.

73 Sentencia de la Corte Suprema de Justicia de la Nación de 24 de octubre de 2000. Campodónico de Beviacqua, Ana Carina c/ Ministerio de Salud y Acción Social -Secretaría de Programas de Salud y Banco de Drogas Neoplásicas s/Recurso de Hecho, considerando 21. Ver Abramovich, Víctor y Courtis, Christian. El umbral de la ciudadanía. El significado de los derechos sociales en el Estado social constitucional. Editores del Puerto, Buenos Aires, 2006, pp. 111-113. 
Así como ha señalado la Corte Constitucional de Colombia el criterio de conexidad "permite amparar derechos no tutelables judicialmente, en principio, siempre y cuando su protección se requiera para la reivindicación de un derecho de carácter indiscutiblemente fundamental". ${ }^{74}$

Como sostiene el magistrado y ex Presidente de la Corte Constitucional colombiana, Hernando Herrera, "no sólo las disposiciones legales o las medidas administrativas son idóneas para el cumplimiento oportuno de los derechos prestacionales, ya que además existen controles a través de las decisiones judiciales que hagan efectiva la realización y protección de los mismos, mediante las acciones de nulidad y restablecimiento del derecho, de los procesos ordinarios y de tutela de acuerdo al grado de competencia señalados en la Constitución o en la ley". ${ }^{75}$

En tal sentido, los tribunales de justicia y el Tribunal Constitucional tiene un rol importante en el deber de los Estados Partes de la Convención Americana de Derechos Humanos, establecida en el artículo $2^{\circ}$, de "adoptar, con arreglo a los procedimientos constitucionales y a las disposiciones de esta Convención, las medidas legislativas o de otro carácter que fueren necesarias para hacer efectivos tales derechos y libertades".

En este contexto, como lo ha determinado la Corte Constitucional colombiana, en sentencia C-109 de 1995:

“Entre las 'medidas de otro carácter' deben incluirse las sentencias de los jueces, y muy particularmente las decisiones de esta Corporación, pues la rama judicial es uno de los órganos del Estado colombiano, y este se ha comprometido a tomar las medidas que sean necesarias para hacer efectivos los derechos de las personas. Por consiguiente, las sentencias de los jueces como medidas de otro carácter diferentes a las leyes, deben buscar hacer efectivos los derechos reconocidos por los pactos de derechos humanos. Es pues legítimo que los jueces, y en particular la Corte Constitucional, integren a la normatividad, al momento de tomar sus decisiones, los derechos reconocidos en la Constitución y en los pactos". ${ }^{76}$

Así en países en que los derechos económicos, sociales y culturales no son asegurados como derechos fundamentales, a diferencia de Chile, como en el caso de Colombia, la Corte Constitucional ha asumido la existencia de una dignidad humana que jamás puede ser desconocida y que otorga contenido básico garantizado a los derechos sociales, determinando un derecho a un "mínimo vital”, como ya lo había establecido la Corte Constitucional alemana, como hemos visto anteriormente.

74 Citada por Herrera Vergara, Hernando. (2000), ob. cit., p. 302. Sentencia Corte Constitucional T-010 de enero 21 de 1999.

75 Herrera Vergara, Hernando. (2000), Ibídem, pp. 296-297. Citada por Herrera, Hernando (2000), ob. cit., p. 297.

76 Citada por Herrera, Hernando (2000), ob. cit., p. 297. 
Así, la Corte Constitucional de Colombia en sentencia SU - 111 de 4 1997, en Sala Plena, ${ }^{77}$ precisó:

“..los derechos económicos, sociales y culturales tienen conexidad con pretensiones amparables a través de la acción de tutela. Ello se presenta cuando se comprueba un atentado grave contra la dignidad humana de personas pertenecientes a sectores vulnerables de la población y el Estado, pudiéndolo hacer, ha dejado de concurrir a prestar el apoyo material mínimo sin el cual la persona indefensa sucumbe ante su propia impotencia. En estas situaciones, comprendidas bajo el concepto de mínimo vital, la abstención o negligencia del Estado se ha identificado como la causante de una lesión directa a los derechos fundamentales que amerita la puesta en acción de las garantías constitucionales”.

La Corte Constitucional colombiana en dicha sentencia agrega:

"Por fuera del principio de la dignidad humana que origina pretensiones subjetivas a un mínimo vital -que impide la completa cosificación de la persona por causa de su absoluta menesterosidad-, la acción de tutela, en el marco de los servicios y prestaciones a cargo del Estado, puede correctamente enderezarse a exigir el cumplimiento del derecho a la igualdad de oportunidades y al debido proceso, entre otros derechos que pueden violarse con ocasión de la actividad pública desplegada en este campo".

Como señala el magistrado Herrera Vergara, citando la sentencia en comento, "el mínimo vital se presenta entonces, 'cuando se comprueba un atentado grave contra la dignidad de personas pertenecientes a sectores vulnerables de la población, y el Estado pudiéndolo hacer, ha dejado de concurrir a prestar el apoyo material mínimo sin el cual la persona indefensa sucumbe ante su propia impotencia'". ${ }^{78}$

A su vez, la Corte Constitucional de Sudáfrica, en sentencia de 4 de octubre de 2000 , en el caso, determinó en el caso "The Government of the Republic of South Africa and others v. Grootboom, Irene and others", que un conjunto de personas que habían sido desalojadas de terrenos privados, incluyendo 510 niños, los cuales reclamaban un alojamiento o refugio provisorio mientras accedían a una habitación permanente, ante ello, la Corte Constitucional sudafricana, en su fallo, ordenó el otorgamiento de refugio o alojamiento a los demandantes por parte del Estado a las familias con niños, imponiendo ciertas condiciones mínimas de salubridad. Frente al recurso interpuesto por el gobierno frente a esta decisión, la Corte Constitucional lo desechó y pasó a examinar la razonabilidad de la política estatal relacionada con el derecho a la vivienda. La Corte sostuvo la justiciabilidad del derecho a la vivienda en los siguientes términos:

"Los derechos económicos y sociales están expresamente reconocidos en la declaración de derechos de la Constitución y no puede decirse de ellos que existen solo en el papel. La sección 7 (2) de la Constitución requiere al Estado respetar,

77 Citada por Herrera, Hernando (2000), ob. cit., p. 298.

78 Herrera Vergara, Hernando (2000). Acción de tutela y derechos prestacionales, ob. cit., p. 298. 
proteger, promover y garantizar los derechos constitucionales y los tribunales están obligados constitucionalmente a asegurar que esos derechos sean protegidos y garantizados. La cuestión entonces no es si los derechos económicos y sociales son justiciables en la Constitución sino cómo los hacemos efectivos en un caso determinado". ${ }^{79}$

La Corte entró a pronunciarse sobre la razonabilidad de la política estatal, advirtiendo previamente que:

"Cuando la Corte en un caso considera la razonabilidad de una medida, no deberá preguntarse si hubieran podido adoptarse otras medidas más deseables o favorables o si, el dinero público hubiera podido utilizarse mejor. La cuestión será si la medida adoptada es razonable. Es necesario reconocer que el Estado cuenta con un amplio espectro de posibles medidas que podría adoptar para cumplir su obligación. Muchas de esas medidas podrían satisfacer el estándar de razonabilidad. Una vez que se demuestra que la medida adoptada satisface el estándar, la obligación del Estado se tiene por cumplida". ${ }^{0}$

Finalmente la Corte Sudafricana declaró vulnerado el derecho a la vivienda y requirió al gobierno sudafricano la corrección de la política de vivienda en la región en que los hechos se produjeron.

El Tribunal Constitucional peruano conforme a la Cuarta Disposición final y Transitoria de la Constitución y al artículo V del Título preliminar del Código Procesal Constitucional, ha determinado que

"[...] la interpretación de los derechos reconocen en el artículo 25 y en el artículo

$2^{\circ}$ inciso 22 de la Constitución debe tenerse presente que.

a) El artículo 24 de la Declaración Universal de Derechos Humanos dispone que toda persona tiene derecho al descanso y al disfrute del tiempo libre.

b) B) El artículo $7^{\circ}$ literal d) del Pacto Internacional de Derechos Económicos, Sociales y Culturales reconoce el derecho de toda persona al goce de condiciones de trabajo equitativas y satisfactorias que le aseguren en especial el disfrute del tiempo libre.

c) El artículo $7^{\circ}$, literal h) del Protocolo Adicional a la Convención Americana sobre Derechos Humanos en materia de derechos económicos, sociales y culturales, reconoce el derecho al descanso y al disfrute del tiempo libre.

d) Consecuentemente de las disposiciones citadas se concluye que:

e) A) La jornada laboral, para ser compatible con el artículo $25^{\circ}$ de la Constitución, deberá considerar que las personas tienen derecho al descanso y al disfrute del tiempo libre, $y$

79 Sentencia citada en Abramovich y Courtis, ob. cit., p. 162.

80 En Abramovich y Courtis, Ibidem, p. 163. 
f) B) El disfrute y compensación del descanso semanal y anual remunerados se regulan por ley o por el convenio, conforme al parámetro constitucional descrito.". ${ }^{1}$

Los casos señalados en diversas materias referentes a derechos económicos, sociales y culturales, muestran que los tribunales están habilitados y pueden dar efectividad y justiciabilidad a los derechos antes mencionados, como a su vez, fijar estándares básicos que deben ser respetados por la legislación y la administración.

Ello no significa que los tribunales deban reemplazar al gobierno en el diseño e implementación de la política de cumplimiento progresivo y cada vez más extendida en cantidad como en calidad del disfrute de los derechos económicos y sociales por parte de toda la población, sino que los tribunales con prudencia deben asegurar y garantizar las dimensiones justiciables de tales derechos.

Las garantías establecidas por el Pacto Internacional de Derechos Económicos, Sociales y Culturales de Naciones Unidas.

La interpretación autorizada del Pacto Internacional de Derechos Económicos, Sociales y Culturales corresponde a su órgano de supervigilancia y control que es el Comité de Derechos Económicos, Sociales y Culturales de Naciones Unidas, el cual emite sus Observaciones Generales y Finales, con el objeto de orientar el cumplimiento de las obligaciones respecto de cada derecho económico, social o cultural contenido en el Pacto, las que son vinculantes para los Estados Parte.

El Comité decidió preparar Observaciones Generales sobre los derechos y disposiciones contenidas en el Pacto a partir de 1988 con el objeto de orientar a los Estados Parte en el cumplimiento de las obligaciones contenidas en dicho Pacto internacional, la presentación de informes y la interpretación de las disposiciones del tratado. Las Observaciones Generales son un sistema que genera una jurisprudencia sobre la interpretación de los contenidos del Pacto, hasta 2006 se habían dictado 18 Observaciones Generales, siendo las últimas dos relacionadas con el derecho al trabajo y en relación a la propiedad intelectual.

El Comité también emite en su tarea de evaluación periódica de los informes de los Estados Parte en su evolución en el cumplimiento de las obligaciones en torno al Pacto, la adopción de Observaciones Finales, que determinan el grado de cumplimiento o incumplimiento de los Estados respecto de las obligaciones emanadas del Pacto Internacional de Derechos Económicos, Sociales y Culturales de Naciones Unidas.

81 Sentencia del Tribunal Constitucional peruano Exp. $\mathrm{N}^{\circ}$ 4635-2004- AA/TC-Tacna, fundamentos jurídi$\cos 18^{\circ}$ y $19^{\circ}$. 


\section{CONSIDERACIONES FINALES}

En un Estado constitucional democrático, todos los derechos humanos o fundamentales indivisibles y complementarios e inalienables deben ser asegurados y garantizados como derivaciones inmediatas y directas de la dignidad de la persona humana. Todos ellos deben tener un contenido constitucionalmente precisado indisponible para los órganos y autoridades del Estado, un contenido esencial indisponible para el legislador, sin el respeto y garantía del mismo, los derechos dejan de ser tales para convertirse en meras proclamaciones líricas sin efecto jurídico efectivo, siendo irreconocibles e impracticables. Dichos contenidos pueden variar de uno a otro derecho, ya que se estructuran en un contexto histórico, cultural y social determinado, el cual varía en el tiempo, posibilitando la profundización y progresividad de dichos contenidos, será siempre tarea del juez constitucional determinar en último término dicho contenido de acuerdo con el texto constitucional. Un enfoque constitucional democrático que asume como valor básico la dignidad de la persona humana en su integralidad en forma coherente no puede dejar ningún derecho fundamental a disposición discrecional del legislador, ya que no hay ningún derecho fundamental que tenga una jerarquía superior a otro, el derecho a la salud y a la educación es tan importante como el derecho a la vida privada, la honra y la libertad de conciencia, para cada uno y todos los seres humanos.

Señalemos asimismo, que antológicamente y estructuralmente los derechos tanto civiles y políticos, como económicos, sociales y culturales, pueden tener garantías constitucionales en un sentido amplio y garantías jurisdiccionales en un sentido específico, su establecimiento no es producto de la estructura de los derechos fundamentales sino de voluntad política de establecer las respectivas garantías, las cuales pueden ser graduales.

La Constitución debe asegurar asimismo las garantías sustantivas e instrumentales que posibiliten un marco fundamental e irreversible en materia de protección de derechos dentro del cual puedan moverse los diferentes operadores políticos y jurídicos, alguno de los cuales ya se encuentra presente en nuestro orden constitucional.

A su vez, frente a las garantías jurisdiccionales de los derechos, no podemos omitir, la crítica de la falta de legitimidad de los jueces para garantizar mediante sentencias el contenido esencial de los derechos sociales, la cual no es de recibo, ya que es la propia Carta Fundamental, por tanto, el poder constituyente, el que les otorga a los tribunales la jurisdicción y competencia para resolver sobre la materia, especialmente en el caso de grupos vulnerables, marginados o subrepresentados a nivel parlamentario. Además, los jueces refuerzan el principio constitucional democrático cuando hacen respetar los derechos constitucionales frente a actuaciones arbitrarias de la administración o de particulares, cuando cautelan el derecho a prestaciones de salud que arbitrariamente son negadas por el respectivo prestados, cuando a un alumno se le priva arbitrariamente del derecho a la educación, cuando se indemniza a una persona por una prestación social deficiente o negligente, cuando un empresario desarrolla conductas antisindicales, para solo señalar algunos ejemplos. En todos estos casos, los 
tribunales hacen respetar y cautelan los derechos fundamentales de las respectivas personas y con ello fortalecen el estado democrático constitucional. Los estados constitucionales democráticos son abiertos en el ámbito del pluralismo político y las decisiones políticas contingentes, pero no son neutrales frente al respeto de la dignidad de la persona humana y el contenido esencial de sus derechos fundamentales. Ningún órgano del Estado cuenta con legitimidad para actuar contra la dignidad de la persona y sus derechos fundamentales, ya que ellos constituyen la base material indisponible de la democracia constitucional. Los tribunales cuentan con legitimidad constitucional para reforzar las bases materiales que den a las personas una vida digna, niveles básicos de autonomía personal y de participación política en los asuntos públicos.

La argumentación de que los jueces no pueden disponer del gasto público ya que ello corresponde a las políticas públicas definidas por el legislador, no es de recibo en su totalidad y debe ser matizada, ya que las decisiones de políticas públicas y gasto público tienen como piso la indisponibilidad del contenido esencial de los derechos constitucionalmente asegurados, como hemos podido demostrar y ejemplificar en este estudio, especialmente de los mínimos de vida digna para los discriminados, vulnerables y marginados, dentro de lo razonable y posible, lo que es empíricamente demostrable. Hagamos la precisión, en todo caso, que la vía jurisdiccional no debiera ser la única ni la más importante de las vías por las cuales la sociedad satisficiera los estándares de vida digna para todos sus integrantes, ya que cada órgano estatal dentro del ámbito de sus competencias debiera hacer su tarea legislativa o administrativa, no en vano ello es una exigencia constitucional en Chile de acuerdo al artículo $5^{\circ}$ inciso $2^{\circ}$ de la Constitución, el respeto y la promoción de cada uno y todos los derechos fundamentales.

El derecho comparado muestra nuevas opciones de garantía del conjunto de los derechos, a través de la consideración de las omisiones legislativas absolutas que afectan el contenido de derechos fundamentales, posibilitando controles de constitucionalidad por omisiones legislativas, por la persistente e irrazonable vulneración de derechos por la negativa a dictar las normas de implementación de ellos, instando a legislar dentro de plazos razonable y reservándose el control de razonabilidad y proporcionalidad de esos productos legislativos, teniendo como parámetro de control los atributos integrantes de los derechos esenciales o fundamentales determinados por la Constitución y el derecho internacional de los derechos humanos.

Finalmente, deben asegurarse y reforzarse los controles democráticos de la sociedad civil respecto de los órganos estatales, posibilitando y reforzando que las políticas públicas respondan a la voluntad del conjunto de la sociedad.

\section{BIBLIOGRAFÍA}

Abramovich, Víctor y Courtis, Christian. (2002). Los derechos sociales como derechos exigibles. (Madrid. Trotta). 
Abramovich, Víctor y Courtis, Christian. (2006). El umbral de la ciudadanía. El significado de los derechos sociales en el Estado social constitucional. (Buenos Aires, Editores del Puerto).

Afonso Da Silva, José. (2002). Impacto da Declaraçáo Universal dos Direitos Humanos na Constituição Brasileira. En Palomino Manchego, José y Remotti Carbonell, José Carlos (Coordinadores). Derechos Humanos y Constitución en Iberoamérica. Lima, Ed. Universidad Nacional de San Marcos - Instituto Iberoamericano de Derecho Constitucional [sección peruana]).

Alexy, Robert. (1993).Teoría de los derechos fundamentales. (Madrid, Centro de Estudios Constitucionales).

Arango, Rodolfo. (2005). El concepto de derechos sociales fundamentales. (Bogotá, Ed. Legis, Universidad Nacional de Colombia).

CançAdo Trindade, António. Protección Internacional de los derechos económicos, sociales y culturales. En Estudios Básicos de Derechos Humanos; I, (San José, Costa Rica, Instituto Interamericano de Derechos Humanos).

Carbonell, Miguel. (2001). La Constitución en serio. Multiculturalismo, igualdad y derechos sociales. (México, Ed. Porrúa - Universidad Nacional Autónoma de México).

Carmona Cuenca, Encarnación. (1992). "Las normas constitucionales de contenido social: delimitación y problemática de su eficacia jurídica”. En Revista de Estudios Políticos $\mathrm{N}^{\circ} 76$, Madrid.

CASAL, Jesús María. (2007). "La protección internacional y constitucional de los derechos sociales”. Casal, Jesús María; Arismendi, Alfredo y Carrillo, Carlos Luis (coordinadores). Tendencias actuales del derecho constitucional. Homenaje a Jesús María Casal Montbrun. Tomo II. (Caracas, Ed. Universidad Central de Venezuela - Universidad Católica Andrés Bello).

Courtis, Christian. (2006). "La prohibición de regresividad en materia de derechos sociales: apuntes introductorias"; en Courtis, Christian. (Comp.). Ni un paso atrás. La prohibición de regresividad en materia de derechos sociales. (Buenos Aires, Editorial Del Puerto).

De Otto y PARDo, Ignacio. (1988). "La regulación del ejercicio de los derechos y libertades. La garantía del contenido esencial en el artículo 53.1 de la Constitución”, en Martín Retortillo, Lorenzo y De Otto y Pardo, Ignacio. Derechos Fundamentales y Constitución. (Madrid, Cuadernos Civitas Derecho Constitucional).

Ferrajoli, L. (2000). "Quali sono i diritti fondamentali?", En Vitale, E. (Editor). Diritti Umani e diritti delle minoranze. (Turín, Ed. Rosenberg \& Sellier).

García Pelayo, Manuel. (1980). Las transformaciones del Estado contemporáneo. (Madrid, Alianza Editorial).

Gavara De Cara, Juan Carlos. (1994). Derechos Fundamentales y Desarrollo legislativo. (Madrid, Ed. Centro Estudios Constitucionales).

Hernández Valle, Rubén. (2002). "Los derechos prestacionales”. En Derechos Humanos y Constitución en Iberoamérica. Palomino Manchego, José y Remotti Carbonell, José Carlos (Coordinadores). (Lima, Ed. Universidad Mayor de San Marcos e Instituto Iberoamericano de Derecho Constitucional [Sección Peruana]), 
Herrera Vergara, Hernando. (2000). Acción de Tutela y derechos prestacionales. En Jurisdicción Constitucional en Colombia. (Santafé de Bogotá, Ed. Corte Constitucional).

Hesse, Konrad. (1992). Escritos de Derecho Constitucional. (Madrid, Ed. Centro de Estudios Constitucionales).

Holmes, Stephan; Sumnstein, Cass. (1999). The cost of rights-Why liberty depends on taxes. W.W. (New York, Norton and Company). Galdino, Flavio. (2005). Introdução a Teria dos Costos dos Direitos - Direitos não nascen em árvores. (Rio de Janeiro, Lúmen Júris).

Imbert, Pierre-Henri. (1989). Droits des pauvres, pauvre droit(s)? Reflexions sur les droits économique, sociaux et culturels, en Revue de Droit Public et de la Science Politique en France et à l'étranger, Nº1, 1989, París, Francia, Ed. LGDJ.

LoBo ToRres, Ricardo. (2003). "La metamorfosis de los derechos sociales en Mínimo Existencial”. En Sarlet, Ingo W. (organizador), Direitos Fundamentais Sociais: estúdios de direito constitucional, internacional e comparado. (Río de Janeiro, Ed. Renovar).

Martínez Estay, José Ignacio. (2003). "Valor e sentido dos direitos sociais". En Direitos Humanos, Teorias e Práticas, (Coimbra, Almedina).

Mayorga Lorca, Roberto. (1990). Naturaleza Jurídica de los Derechos Económicos, Sociales y Culturales. segunda edición, (Santiago, Ed. Jurídica de Chile).

MichelmanN, Franck. (1979). "Welfare Rights in a Constitutional Democracy". En Washington University Law Quaterly, Vol. 03. 1979 (Washington, Washington University Press).

Nogueira AlCalá, Humberto. (2008). Derechos fundamentales y garantías constitucionales. (Santiago, Ed. Librotecnia).

Nogueira AlcalÁ, Humberto. (2003). "Los derechos esenciales o humanos contenidos en los tratados internacionales y su ubicación en el ordenamiento jurídico nacional: doctrina y jurisprudencia”. En Revista lus et Praxis, año $9 N^{\circ}$ 1, 2003, pp. 403-466.

Ojeda Marín, A. (1996). Estado social y crisis económica. (Madrid, Ed. Universidad Complutense).

PANSIERI, Flavio. (2006). "Condicionantes a sindicabilidade dos Direitos Sociais", em Revista da Academia Brasileira de Direito Constitucional, Volumen 10 A, (Curitiba, Editora Jurua).

Pisarello, Gerardo. (2002). "Del Estado social tradicional al Estado social constitucional: por una protección compleja de los derechos sociales”, en Carbonell, Miguel (Compilador), Teoría Constitucional y derechos fundamentales. (México, Ed. Comisión Nacional de Derechos Humanos).

Pisarello, Gerardo. (2001). "Del Estado Social legislativo al Estado social Constitucional: por una protección compleja de los derechos sociales”. En Revista Isonomía $N^{\circ}$ 14, 2001, (Madrid, Cedam).

Poyal Costa, Ana. (1991). "La eficacia de los derechos humanos frente a terceros". En Revista de Derecho Político $N^{\circ} 34$ (1991), Madrid.

Rossı, Julieta. (2006). La obligación de no regresividad en la jurisprudencia del Comité de Derechos Económicos, Sociales y Culturales", en Courtis, Christian. (Comp.). Ni un paso atrás. La prohibición de regresividad en materia de derechos sociales. (Buenos Aires, Editorial Del Puerto). 
Sarlet, Ingo Wolfgang. (2009). Dignidade da Pessoa Humana e Direitos Fundamentais na Constituicao Federal de 1988. Séptima edición revisada y actualizada. (Porto Alegre, Livreria Do Advogado Editora), p. 67.

Corte Interamericana de Derechos Humanos

- Corte Interamericana. Caso "Cinco Pensionistas" Vs. Perú. Sentencia de 28 de febrero de 2003. Serie C No. 98

- Corte Interamericana de Derechos Humanos, Caso “Instituto de reeducación del menor vs. Paraguay, sentencia de 2 de septiembre de 2004.

- Sentencia de la Corte Interamericana de Derechos Humanos. Caso Comunidad Indígena Yakse Axa c. Paraguay. Sentencia de 17 de junio de 2005.

- Sentencia de la Corte Interamericana de Derechos Humanos, de 26 de septiembre de 2006. Serie $C \mathrm{~N}^{\circ} 154$.

Comisión Interamericana de Derechos Humanos

- El acceso a la justicia como garantía de los derechos económicos, sociales y culturales. Estudio de los estándares fijados por el sistema interamericano de derechos humanos. Washington DC, OEA Documentos oficiales 2007, OEA/Ser.L/V/II, párrafo 241.

- Comisión Interamericana de Derechos Humanos. Informe sobre la situación de los derechos humanos en el Ecuador. OEA/Ser. L/V/II.96, Doc. 10 rev. I, 24 de abril de 1997.

- Comisión Interamericana de Derechos Humanos. Segundo informe sobre los derechos humanos en el Perú, OEA/ Ser. L/V/II. 106 de junio 2000.

Comité de Derechos Económicos, Sociales y Culturales de Naciones Unidas

- Observación General 3, "La índole de las obligaciones de los Estados Parte”, 1990,

- Comité de Derechos Económicos, Sociales y Culturales de Naciones Unidas. Observación General 4.

- Observación General Nº 9, E/C. 12/1998/24, 3 de diciembre de 1998.

Sentencia de la Corte Suprema de Justicia de Argentina

- Sentencia de la Corte Suprema de Justicia de la Nación de 24 de octubre de 2000. Campodónico de Beviacqua, Ana Carina c/ Ministerio de Salud y Acción Social -Secretaría de Programas de Salud y Banco de Drogas Neoplásicas s/Recurso de Hecho.

Sentencias de la Corte Constitucional de Colombia

- Sentencia de la Corte Constitucional de Colombia, ST-533 de 1992.

- Sentencia de la Corte Constitucional de Colombia, C-251 de 1997.

- Sentencia de la Corte Constitucional de Colombia, T- 595 de 2002.

- Sentencia de la Corte Constitucional de Colombia, C-776 de 2003.

- Sentencia de la Corte Constitucional de Colombia, T-680-2003.

Sentencia de la Sala Constitucional de la Corte Suprema de Costa Rica.

- Sentencia de $1^{\circ}$ de julio de 2009, Exp: 09-007505-0007-Co; Res: 2009-10553. 
Sentencia del Tribunal Constitucional chileno

- Sentencia del Tribunal Constitucional chileno, Rol N ${ }^{\circ}$ 740-07, de 18 de abril de 2008.

- Sentencia del Tribunal Constitucional chileno Rol N 976, de 26 de junio de 2008.

- Sentencia del Tribunal Constitucional, chileno Rol 1361-09, de trece de mayo de 2009.

Sentencia del Tribunal Constitucional del Perú

- Sentencia del Tribunal Constitucional peruano Exp. $N^{\circ}$ 4635-2004- AA/TC-Tacna, fundamentos jurídicos $18^{\circ}$ y $19^{\circ}$.

Sentencias de Jurisdicciones constitucionales europeas

- Sentencia de la Corte Constitucional alemana, BverfGE 84, 133.

- Sentencia de la Corte Constitucional alemana, BverfGE 27, 253.

- Sentencia de la Corte Constitucional alemana, BverfGE 75, 348.

- Sentencia de la Corte Constitucional alemana, BverfGE 40, 121.

- Sentencia de la Corte Constitucional alemana, BverfGE 56, 139.

- Sentencia del Tribunal Constitucional de Portugal, $N^{\circ}$ 509/2002, del 19 de diciembre de 2002. 